\title{
Review \\ Understanding the Central Role of Citrate in the Metabolism of Cancer Cells and Tumors: An Update
}

\author{
Philippe Icard ${ }^{1,2,3, *}$, Antoine Coquerel ${ }^{1,4}$, Zherui Wu ${ }^{5} \mathbb{D}$, Joseph Gligorov ${ }^{6}$, David Fuks ${ }^{7}$, Ludovic Fournel ${ }^{3,8}$, \\ Hubert Lincet ${ }^{9,10}$ and Luca Simula ${ }^{11}$ (D)
}

check for updates

Citation: Icard, P.; Coquerel, A.; Wu, Z.; Gligorov, J.; Fuks, D.; Fournel, L.; Lincet, H.; Simula, L. Understanding the Central Role of Citrate in the Metabolism of Cancer Cells and Tumors: An Update. Int. J. Mol. Sci. 2021, 22, 6587. https://doi.org/ $10.3390 /$ ijms 22126587

Academic Editors: Eric Parkinson,

Maria E. Mycielska and

Sebastian Haferkamp

Received: 19 May 2021

Accepted: 16 June 2021

Published: 19 June 2021

Publisher's Note: MDPI stays neutral with regard to jurisdictional claims in published maps and institutional affiliations.

Copyright: (c) 2021 by the authors. Licensee MDPI, Basel, Switzerland. This article is an open access article distributed under the terms and conditions of the Creative Commons Attribution (CC BY) license (https:// creativecommons.org/licenses/by/ $4.0 /)$.
1 Medical School, Université Caen Normandie, CHU de Caen, 14000 Caen, France; antoine.coquerel@gmail.com

2 UNICAEN, INSERM U1086 Interdisciplinary Research Unit for Cancer Prevention and Treatment, Normandie Université, 14000 Caen, France

3 Service de Chirurgie Thoracique, Hôpital Cochin, Hôpitaux Universitaires Paris Centre, APHP, Paris-Descartes University, 75014 Paris, France; ludovic.fournel@aphp.fr

4 INSERM U1075, COMETE Mobilités: Attention, Orientation, Chronobiologie, Université Caen, 14000 Caen, France

5 School of Medicine, Shenzhen University, Shenzhen 518000, China; wuzherui@gmail.com

6 Oncology Department, Tenon Hospital, Pierre et Marie Curie University, 75020 Paris, France; joseph.gligorov@aphp.fr

7 Service de Chirurgie Digestive et Hépato-Biliaire, Hôpital Cochin, Hôpitaux Universitaires Paris Centre, APHP, Paris-Descartes University, 75014 Paris, France; david.fuks@aphp.fr

8 Descartes Faculty of Medicine, University of Paris, Paris Center, 75006 Paris, France

9 INSERM U1052, CNRS UMR5286, Cancer Research Center of Lyon (CRCL), 69008 Lyon, France; hubert.lincet@univ-lyon1.fr

10 ISPB, Faculté de Pharmacie, Université Lyon 1, 69373 Lyon, France

11 Department of Infection, Immunity and Inflammation, Institut Cochin, INSERM U1016, CNRS UMR8104, University of Paris, 75014 Paris, France; luca.simula@inserm.fr

* Correspondence: philippe.icard@aphp.fr

Abstract: Citrate plays a central role in cancer cells' metabolism and regulation. Derived from mitochondrial synthesis and/or carboxylation of $\alpha$-ketoglutarate, it is cleaved by ATP-citrate lyase into acetyl-CoA and oxaloacetate. The rapid turnover of these molecules in proliferative cancer cells maintains a low-level of citrate, precluding its retro-inhibition on glycolytic enzymes. In cancer cells relying on glycolysis, this regulation helps sustain the Warburg effect. In those relying on an oxidative metabolism, fatty acid $\beta$-oxidation sustains a high production of citrate, which is still rapidly converted into acetyl-CoA and oxaloacetate, this latter molecule sustaining nucleotide synthesis and gluconeogenesis. Therefore, citrate levels are rarely high in cancer cells. Resistance of cancer cells to targeted therapies, such as tyrosine kinase inhibitors (TKIs), is frequently sustained by aerobic glycolysis and its key oncogenic drivers, such as Ras and its downstream effectors MAPK/ERK and PI3K/Akt. Remarkably, in preclinical cancer models, the administration of high doses of citrate showed various anti-cancer effects, such as the inhibition of glycolysis, the promotion of cytotoxic drugs sensibility and apoptosis, the neutralization of extracellular acidity, and the inhibition of tumors growth and of key signalling pathways (in particular, the IGF-1R/AKT pathway). Therefore, these preclinical results support the testing of the citrate strategy in clinical trials to counteract key oncogenic drivers sustaining cancer development and resistance to anti-cancer therapies.

Keywords: citrate; cancer cells; Warburg effect; ACLY; resistance to therapies

\section{Introduction}

Citrate is produced from oxaloacetate (OAA) and acetyl-CoA by citrate synthase (CS) in mitochondria, and it plays a central role in both normal and cancer cell metabolism [1] In mitochondria, as an intermediate of the tricarboxylic acid (TCA) cycle (also known as the Krebs cycle), citrate sustains the generation of reduced nicotinamide adenine dinucleotide 
$(\mathrm{NADH})$ and flavine adenine dinucleotide $\left(\mathrm{FADH}_{2}\right)$ molecules, which lead to ATP production via ATP synthase, the complex V of the Electron Transport Chain (ETC). Remarkably, citrate plays several additional roles in cells [1]. Indeed, it can be exported into the cytosol, where it is converted by ATP-citrate lyase (ACLY) back into acetyl-CoA and OAA. Cytosolic acetyl-CoA sustains fatty acid (FA) synthesis (FAS), and it also regulates the activities of proteins, particularly histones (required for DNA transcription), through acetylation. Cytosolic OAA can be converted into phosphoenolpyruvate (PEP) to generate glucose via gluconeogenesis, or it can sustain nucleotide and polyamine synthesis after transformation into aspartate. Therefore, citrate is a gauge of nutrients available for biosynthesis and ATP production generated via oxidative phosphorylation (OXPHOS). In addition, citrate is a key regulatory molecule, which targets (directly or indirectly) catabolic and anabolic pathways (fatty acid $\beta$-oxidation (FAO) and FAS, glycolysis, and gluconeogenesis) in a manner such that when one pathway is activated, the other is inhibited. For example, citrate directly inhibits the main regulators of glycolysis, phosphofructokinase-1 (PFK1) and phosphofructokinase-2 (PFK2) [2,3], while it enhances gluconeogenesis by promoting fructose-1,6-biphosphatase (FBPase) [4].

An example of the key role of citrate in normal cells can be found in hepatocytes. In these non-proliferative cells, when glucose is abundant (such as after meal), insulin promotes the conversion of glucose into acetyl-CoA, and then citrate [5,6]. Subsequently, citrate is exported in the cytosol, sustaining FAS in hepatocytes and leading to fat storage in adipocytes via lipoproteins [5]. In contrast, when the glucose serum level is low, the hormone glucagon promotes lipolysis and subsequent FAO in liver. FAO transforms FAs into acetyl-CoA, which is then converted by CS into citrate, fuelling the TCA cycle coupled to ATP production. In addition, glucagon promotes gluconeogenesis, a pathway consuming ATP, to supply glucose for the brain and erythrocytes [5,7]. Different sources can be used to obtain the carbons required to generate glucose by gluconeogenesis, such as lactate, amino acids (in particular, alanine), acetone (a ketone body (KB)), or glycerol (derived from the hydrolysis of triglycerides). Importantly, in the context of FAO-coupled gluconeogenesis, the high cytosolic concentration of citrate (resulting from its mitochondrial export) directly inhibits the glycolytic enzymes PFK2 and PFK1 [8]. Thus, through this so-called Randle cycle regulation [7], glycolysis is nearly switched off, while fat degradation, gluconeogenesis and the production of glucose are favoured [2]. Moreover, citrate is involved in numerous physiological processes and regulations, such as insulin secretion [9], prostatic fluid and spermatozoid mobility [10], the formation and strength of dental and bone tissues [11,12], immune and inflammatory response, and anti-bacterial defence [13-17]. Consequently, the deregulation of citrate metabolism is observed in various pathologies, particularly obesity, diabetes, inflammation, and cancer. Interestingly, citrate is used for disinfection and in food preservatives against Clostridium botulinum, an anaerobic Gram-positive pathogen [18]. In addition, citrate shows antibacterial activity against other proliferative gram-positive species, such as Staphylococci, and yeast-like fungi, such as Candida albicans $[19,20]$.

In proliferative cancer cells, which are not censored by suppressive controls, a metabolic deregulation is promoted by the high metabolic turnover, resulting in the maintenance of citrate in a low concentration range, a mechanism that we have considered to be a key driving force for the Warburg effect (i.e., enhanced aerobic glycolysis with lactic acid production even in the presence of oxygen) [1,21-23]. Several years ago, we were the first to demonstrate that citrate, a well-known inhibitor of PFK and the Pasteur effect (i.e., anaerobic fermentation in yeast) [24], inhibits the proliferation of various cancer cells of solid tumors (human mesothelioma, gastric and ovarian cancer cells) at high concentrations (10-20 mM), promoting apoptosis and the sensitization of cells to cisplatin [25-27].

In line with our hypothesis that a low citrate level promotes the Warburg effect, it has been shown that the inhibition of paclitaxel-resistant lung cancer cells' proliferation by dichloroacetate is associated with increasing cytosolic citrate concentration [28]. Moreover, citrate level was found depleted in malignant mesothelioma cells (compared to non-malignant cells) [29], and microRNA-126, which suppresses tumor growth, also 
restored citrate level through the inhibition of ACLY and the Protein Kinase B (also named $\mathrm{Akt})$, a pathway promoting ACLY activation [29].

In this review, we will synthetize the preclinical results of the literature on citrate in cancer cells and we will try to explain or answer several questions. Why does a low concentration of citrate promote the Warburg effect and cancer aggressiveness? Which level of citrate can be expected in cells preferentially relying on oxidative metabolism [30,31]? What could be the impact on the tumor microenvironment (TME) of citrate administration at high doses? Lastly, which citrate strategy do we recommend for testing in clinical trials?

\section{The Central Role of Citrate in the Warburg Effect}

In normal cells, such as liver cells, citrate regulates several strategic enzymes of both catabolic and anabolic pathways. Indeed, citrate inhibits the main glycolytic enzymes PFK1 and PFK2, while at the same time it enhances the activity of the enzymes acetyl-CoA carboxylase (ACC) (driving FAS) and fructose-1,6-bisphosphatase (FBPase) (promoting gluconeogenesis) $[2,8]$. Thus, citrate acts as a gauge, which switches off glycolysis and concomitantly switches on gluconeogenesis and FAS.

Of note, malonyl-CoA (a derivate of citrate) further sustains FAS and inhibits its inverse metabolic pathway (i.e., the $\mathrm{FAO}$ ) through a direct downregulation of the carnitine acyltransferase 1 (CPT1), the enzyme responsible for the transfer of FA-derived acyl-CoA into mitochondria [32]. As we will see, these regulations are impaired in cancer cells, and a low citrate level, resulting from the rapid turnover of molecules, appears as a key driver of the Warburg effect.

\subsection{The Warburg Effect}

Numerous cancer cells rely on aerobic glycolysis, a metabolism first identified by Otto Warburg [23], and extensively studied in recent years [33,34], in particular to understand how it can promote cancer cells' aggressiveness and drug resistance [21,35]. Briefly, elevated glucose uptake sustains biosynthesis since glycolysis and its branched pathways support the synthesis of precursors of several macromolecules. By a cascade of ten enzymatic reactions, glucose is transformed into pyruvate, and a great part of this pyruvate is converted by lactate dehydrogenase A (LDHA) into lactate. However, in cancer cells, the re-expression of pyruvate kinase (PK) in its embryonic dimeric form PKM2, which is less active than the tetrameric form, creates a "bottleneck" at the end of glycolysis, promoting the accumulation of upstream glycolytic intermediates. Consequently, these intermediates can feed branched pathways, in particular the glycerol pathway, required for lipid synthesis, and the glycine-serine-methionine pathway, required for nucleotide and polyamine synthesis. Glucose metabolism can be also channelled towards the pentose phosphate pathway (PPP), whose oxidative part generates the reduced nicotinamide adenine dinucleotide phosphate $\left(\mathrm{NADPH}, \mathrm{H}^{+}\right.$) required for redox balance, nucleotide synthesis and FAS. Of note, lysine acetylation of metabolic enzymes is a key posttranslational regulation, which adapts the activities of the metabolic enzymes to nutrients availability, as showed in human liver tissue [36]. In cancer cells, a high glucose consumption promotes PKM2 acetylation on lysine 305, and thus its inactivation [37]. Monomeric PKM2 (less active than tetrameric PKM2) also translocates into the nucleus during G1 phase, promoting concomitant activation of Myelocytomatosis Viral Oncogene (MYC) and cell cycle progression, resulting in the stimulation of glycolytic gene expression and active transcription of hypoxia-inducible factor- $1 \alpha$ (HIF-1 $\alpha$ ), a key inducer of the Warburg effect (for references, see [38]). It is worth noting that cancer cells metabolize glutamine too, which, once transformed into glutamate and then $\alpha$-ketoglutarate (AKG), sustains the TCA cycle and the mitochondrial production of ATP. However, the complete oxidation of one molecule of glutamine results in less ATP molecules than the complete oxidation of glucose and palmitate (9 ATP, 36 ATP and 106 ATP, respectively). Importantly, glutamine metabolism-coupled with glycolysis-provides nitrogen groups and aspartate, which sustains nucleotide and polyamines synthesis. 
In these aerobic glycolysis-based cancer cells, citrate can be generated in mitochondria from acetyl-CoA and OAA by CS. While a reduced flux of pyruvate into mitochondria is still able to provide the required acetyl-CoA (a major part of pyruvate being converted into lactate), OAA is presumably mainly derived from the glutamine through the conversion into AKG (Figure 1). However, in hypoxic cancer cells or in cells harbouring mutations of enzymes in the TCA cycle or in the ETC, an alternative reductive glutamine-dependent pathway can be the dominant means of citrate production. In this case, the carboxylation of AKG derived from glutamate leads directly to isocitrate, and then citrate, without the involvement of acetyl-CoA and OAA [39].

Cancer Cells

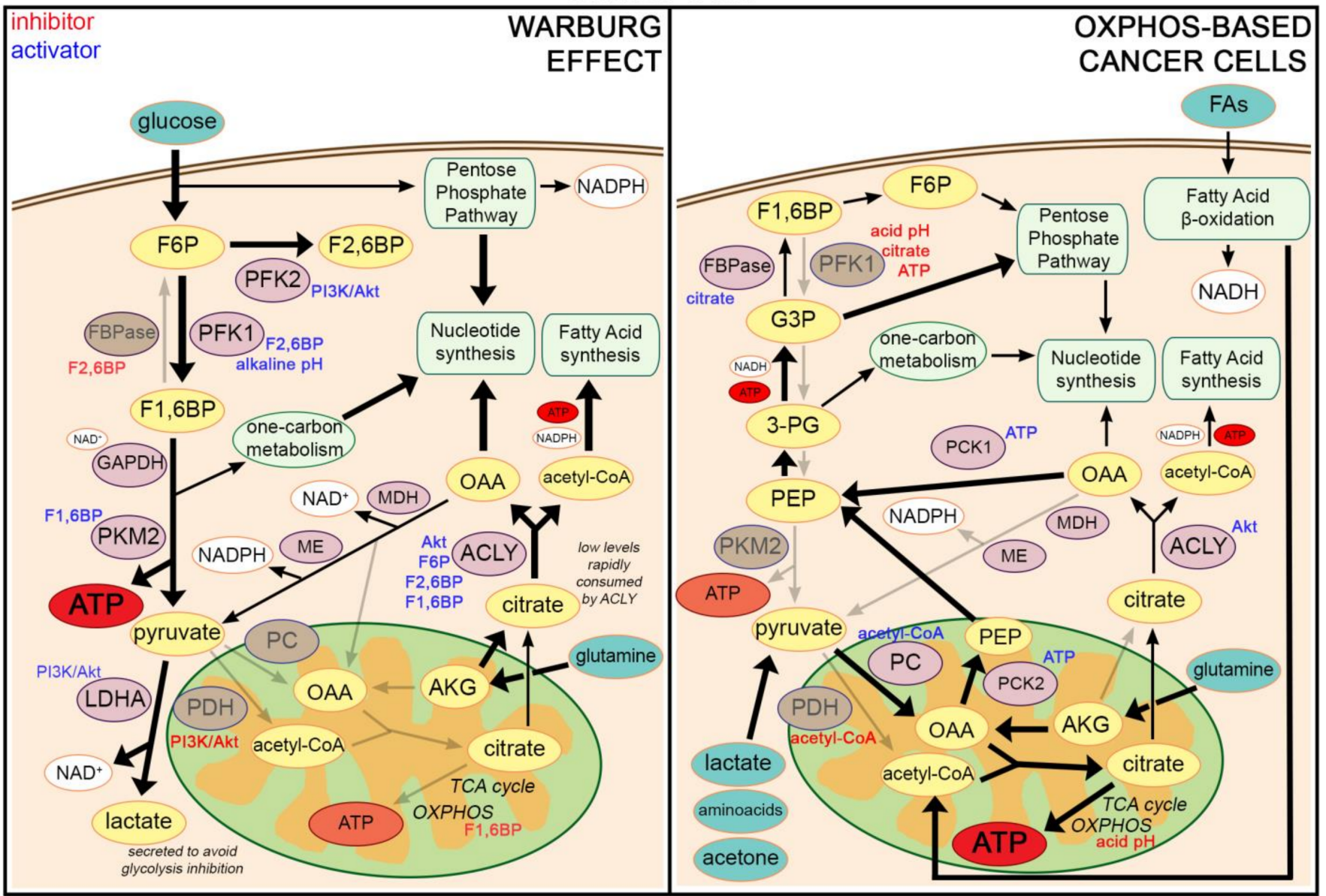

Figure 1. Citrate fate in cancer cells. Enzymes are indicated in pink (active) or brown (inactive). Metabolites are in yellow (intracellular) or green (when uptaken from the extracellular environment). Key cellular processes are in light green. Specific regulators of protein activities are indicated in blue (activators) or red (inhibitors). Arrow size is proportional to pathway engagement (in gray if the pathway is not active). Differences in glycolytic and mitochondrial ATP production are highlighted using a different font size. Small ATP and NAD $(\mathrm{P}) \mathrm{H}$ boxes (not originating from an arrow) indicate their requirement to sustain the corresponding cellular processes (FAS from acetyl-CoA, 3-PG to G3P conversion, and GAPDH activity). On the left side, the functioning of cells relying on the Warburg effect is summarized. Glucose is channelled into glycolysis to produce ATP. Moreover, a portion of glycolytic intermediates is diverted toward the PPP and the serine one-carbon metabolism to sustain nucleotide synthesis. Since pyruvate is preferentially transformed by LDHA into lactate (with regeneration of $\mathrm{NAD}^{+}$required for GAPDH functioning), it poorly supports the generation of citrate from acetyl-CoA and OAA in mitochondria. Consequently, citrate can be derived mainly from glutamine via AKG. Moreover, citrate is rapidly converted by ACLY into OAA (sustaining nucleotide synthesis and/or being recycled into malate and pyruvate) and 
acetyl-CoA (sustaining lipid synthesis and histone acetylation). On the right side, the functioning of cells relying on oxidative metabolism is depicted, in particular FAO, a condition observed especially in case of glucose deprivation. High levels of mitochondrial acetyl-CoA (derived from FAO) and OAA (derived from various carbon sources being converted into pyruvate) sustains the production of high levels of citrate. Citrate is used to a minor extent in the TCA cycle to support ATP synthesis, and it is mainly exported in the cytosol to sustain the synthesis of nucleotides and de novo FAS, as seen in glucosebased cancer cells. However, cytosolic OAA can be also diverted towards the production of PEP to feed gluconeogenesis. The latter pathway is required to support nucleotide synthesis via PPP and serine one-carbon metabolism. Of note, oscillatory levels of citrate may promote futile cycles, such as the alternance between glycolysis (when citrate is low) and gluconeogenesis (when citrate is high) or between FAO (promoted by low citrate via low malonate levels) and FAS (promoted by high citrate via high malonate levels). Furthermore, high consumption of citrate to sustain biosynthesis can induce a low citrate level, promoting a truncated gluconeogenesis due to FBPase inactivation (not figured). Abbreviations: ACLY: ATP citrate lyase, AKG: $\alpha$-ketoglutarate (also known as 2-oxoglutarate), AKT: Protein Kinase B, F1,6P: Fructose-1,6-bisphosphate, F2,6BP: Fructose-2,6-biphosphate, F6P: Fructose 6-phosphate, FAs: Fatty acids, FAO: Fatty acid $\beta$-oxidation, FAS: Fatty acid synthesis, FBPase: fructose-1,6-bisphosphatase, G3P: Glyceraldehyde-3-phosphate, LDHA: Lactate dehydrogenase A, MDH: Malate dehydrogenase, ME: Malic enzyme, $\mathrm{NAD}^{+}$: Nicotinamide adenine dinucleotide oxidized, NADPH: Nicotinamide adenine dinucleotide phosphate, OAA: Oxaloacetate, OXPHOS: Oxidative phosphorylation, PC: Pyruvate carboxylase, PDH: Pyruvate dehydrogenase, PEP: Phosphoenolpyruvate, PCK: Phosphoenolpyruvate carboxylase, PFK1: Phosphofructokinase 1, 3-PG: 3 Phosphoglycerate, PI3K: phosphatidylinositol-3-kinase, PPP: pentose phosphate pathway, PKM2: Pyruvate kinase muscle embryonic isozyme 2, TCA cycle: tricarboxylic acid cycle.

In highly glycolytic cells, the mitochondrial production of ATP is reduced. This is due to the inhibition of the OXPHOS by the high levels of the glycolytic intermediate fructose-1,6-bisphosphate (F-1,6-BP), a process likely explaining the Crabtree effect, i.e., the inhibition of cell respiration by high concentrations of glucose [40]. Therefore, the carbon flux in the TCA cycle is downregulated, and citrate is mainly exported in the cytosol, where it is transformed by ACLY into acetyl-CoA and OAA. Importantly, mitochondrial aconitase (ACO2) (the enzyme metabolizing citrate in the TCA cycle) maintains a high citrate/isocitrate ratio, thus favoring the export of citrate into the cytosol, particularly in prostate epithelial cells [41]. Therefore, ACO2 plays a key regulatory role in mitochondria, either sustaining the functioning of the TCA cycle (and thus, ATP production) or promoting the efflux of citrate (coupled with histone acetylation and/or FAS) [42-45]. Of note, cytosolic OAA can be converted into malate by malate-dehydrogenase (MDH), this reaction regenerating $\mathrm{NAD}^{+}$from $\mathrm{NADH}$, a cofactor required for the functioning of glycolysis at the glyceraldehyde-3-phosphate dehydrogenase (GAPDH) level. Then, malate derived from OAA enters into mitochondria in exchange with citrate via the mitochondrial citrate/isocitrate carrier (CIC), also known as SLC25A1 [46]. Alternatively, malate can be converted by malic enzyme (ME) into pyruvate, this reaction producing $\mathrm{NADPH}, \mathrm{H}^{+}$. OAA can be also transformed by cytosolic phosphoenolpyruvate carboxykinase (PCK1) into PEP (which sustains gluconeogenesis), or by aspartate aminotransferase (AST) into aspartate (which sustains nucleotide synthesis and polyamine synthesis) (Figure 1).

In the TME, hypoxia may further promote the Warburg effect in cancer cells. Indeed, the main hypoxia-induced transcription factor, HIF- $1 \alpha$, upregulates glucose membranes transporters (GLUT1, GLUT3) and several key glycolytic enzymes, such as hexokinase 2 (HK2), PFK, phosphoglycerate kinase1 (PGK1), PKM2, PFK2 and LDHA [47]. In addition, HIF- $1 \alpha$ activates the gene encoding the kinase pyruvate dehydrogenase kinase 1 (PDK1), which inhibits the transformation of pyruvate into acetyl-CoA by pyruvate dehydrogenase (PDH) [48]. Consequently, pyruvate is preferentially converted into lactate by LDHA. Lactate is secreted in the extracellular environment, favouring its acidification, which is a phenomenon associated with cancer invasiveness, aggressiveness, angiogenesis, suppression of the immune response, and resistance to therapies [49,50]. Importantly, the concomitantly decreased mitochondrial functioning favours the establishment of an alkaline cytosolic $\mathrm{pH}$, a condition enhancing PFK1 activity [8,51]. Moreover, the downregulation of oxidative metabolism limits the production of reactive oxygen species (ROS) in an adequate range with active proliferation [52], while the limited synthesis of ATP and 
citrate avoids the negative allosteric inhibition exercised by these molecules on PFK1 and PFK2 [8].

Lastly, the Warburg effect in cancer cells is further promoted by mutations in key oncogenes, such as MYC, Kristen rat sarcoma viral oncogene homolog $(R A S)$, and its downstream targets phosphatidylinositol-3-kinase/Akt/ mammalian target of rapamycin (PI3K/AKT/mTOR) signaling pathway, or oncosuppressor genes, such as TP53 inhibiting glycolysis and Phosphatase and TENsin homolog (PTEN) inhibiting PI3K/AKT/mTOR. These proteins are also key regulators of cellular metabolism and energy production, and their mutations may further contribute to the Warburg effect [53,54]. MYC is also a key inducer of glutaminolysis [55]. Of note, CS knockdown promotes aerobic glycolysis in cancer cells with the induction of epithelial-to-mesenchymal transition (EMT), a phenotype which was completely reversed by p53 reactivation [56]. Although the high dependence of these cancer cell types on glycolysis correlates with a higher resistance to treatments and a poor survival, as observed in non-small-cell lung cancer (NSCLC) [57,58], it may constitute a vulnerability that could be targeted for therapy. Importantly, resistance to targeted therapies, such as Tyrosine Kinase inhibitors (TKIs), are sustained by aerobic glycolysis and its key oncogenic drivers, such as Ras and its downstream effectors MAPK/ERK and PI3K/Akt [59,60].

\subsection{A Low Citrate Level Is a Driving Force for the Warburg Effect}

Citrate is a well-known inhibitor of PFK2 [61] - the key activator of PFK1—as showed, in particular, in ascites cancer cells [3]. PFK2 converts fructose-6-phosphate (F-6-P) into fructose-2,6-bisphosphate (F-2,6-BP), which is a potent allosteric activator of PFK1, and thus of glycolysis [8,62]. PKF2 is a bidirectional enzyme (also named phosphofructo-2kinase/fructose-2,6-bisphosphatase (PFKFB)) with several isoforms [61,63]. The PFKFB3 isoform, frequently upregulated in cancer cells, has a high kinase activity [62], and thus, it promotes PFK1 and the generation of F-1,6-BP. This molecule is then channelled into the second part of glycolysis, ultimately leading to the production of ATP and pyruvate. Moreover, F-1,6-BP enhances the glycolytic ATP production since it is a well-known allosteric activator of PK $[8,64]$, including the embryonic PKM2 isoform, frequently re-expressed in cancer cells $[65,66]$.

Importantly, F-1,6-BP induces an additional feedback loop which may enhance the Warburg effect. Indeed, F-1,6-BP can bind to Son-of-Sevenless-homolog-1 (SoS1) [67], which catalyses Ras activation [68]. In turn, Ras promotes the central mitogen-activated protein kinase (MAPK) pathway (its usual downstream targets), and also PI3K/Akt [69]. Of note, in triple-negative breast cancer (TNBC) cells, it was shown that epidermal growth factor (EGF) signaling activates the first step of glycolysis, and F-1,6-BP directly binds to epidermal growth factor receptor (EGFR), enhancing its activity [70]. Therefore, through EGFR and/or direct binding to SoS1, F-1,6-BP can directly promote Ras/PI3K/Akt signaling, which in turn activates both PFK2/PFKFB3 and HIF-1 $\alpha$, further supporting glycolysis $[62,71]$. In parallel, F-2,6-BP promotes a truncated gluconeogenesis by inhibiting FBPase [4,8,72].

One of the main characteristics of the Warburg effect is also the concomitant downregulation of the oxidative metabolism, a process that reduces ATP production and favors the export of citrate in the cytosol. This effect is achieved in cancer cells by a cooperation between PI3K/Akt and F-1,6-BP. Indeed, Akt, which promotes LDHA activity [47], concomitantly activates PDK1, a kinase inhibiting pyruvate conversion into acetyl-CoA [40,73]. In parallel, $\mathrm{F}-1,6-\mathrm{BP}$ reinforces this mitochondrial downregulation and promotes glycolysis by directly inhibiting the activity of the complexes III and IV of the ETC [40]. Consequently, the mitochondrial production of ATP and citrate are limited, and this prevents the inhibition of PFK2/PFKFB3 and PFK1 by high levels of these molecules, especially citrate, a potent inhibitor of PFK2 [3]. Of note, in normal cells, the mechanism of citrate inhibition on PFK2 is non-competitive for ATP [61].

In sum, a vicious cycle is created in glycolytic cancer cells, avoiding high levels of citrate counteracting the major oncogenic drivers of the Warburg effect (namely Akt and 
HIF-1 $\alpha$ ) [74]. This regulation results in an enhancement of the activity of the enzymes PFK2, PFK1, LDHA, and PDK1 in a positive feedback loop. Coherently with this, in vitro studies have shown that citrate administered at high concentrations inhibits PFK1 [75,76], PFK2 [3], and also PTEN, the key inhibitor of PI3K/Akt [77,78].

At the same time, low citrate levels downregulate FBPase, favoring a truncated gluconeogenesis, and thus the possible generation of ribose-5-phosphate (R5P) required for nucleotide synthesis $[4,72]$. If not, high citrate levels would enhance FBPase activity, thus allowing the functioning of the end part of gluconeogenesis, with concomitant downregulation of PFK2 and PFK1 [4,22]. Of note, FBPase is now considered as a onco-suppressor that could inhibits HIF-1 $\alpha$ [72]. Interestingly, the low citrate levels observed in malignant mesothelioma cells can be restored by microRNA-126 overexpression, a treatment which efficiently suppresses tumor growth, and inactivates ACLY and the insulin receptor substrate-1 (IRS-1)/Akt pathway [29]. This IRS-1 pathway plays a key role in transmitting signals from the insulin and insulin-like growth factor-1 (IGF-1) receptors to the intracellular pathways PI3K/Akt and MAPK/ERK [79].

Remarkably, cancer cells frequently upregulate ACLY, thus accelerating the transformation of citrate to sustain biosynthesis $[80,81]$. ACLY is an enzyme that is directly activated by Akt [82,83], and by phosphorylated sugars (such as F-6-P, F-2,6-BP and F-1,6-BP) [84]. By upregulating ACLY both via phosphorylation and transcriptional upregulation [85], the PI3K/Akt pathway favors histone acetylation [86], leading to increased lipid and cholesterol synthesis. Consequently, the engagement of glycolysis (sustained by glucose abundance) is coupled with the rapid turnover of molecules such as citrate, which sustains biosynthesis, a turnover favoured by ACLY upregulation and downregulation of OXPHOS. As a result, the glycolytic pathway cannot be inhibited by ATP and citrate, while the biosynthesis sustained by the Warburg effect is not arrested. In addition, ACLY can promote the EMT phenotype in cancer cells [87] (presumably by regulating Snail expression) and stemness $[80,81,88]$. In this setting, PI3K/Akt and ACLY activate the canonical WNT/ $\beta$-catenin pathway, which promotes EMT and the development of fibrotic tumor stroma, as well as exhaustion of immune response and cell cycle progression [89-91]. Of note, EMT has also been related to the emergence of cancer stem cells (CSCs) [92], which could, therefore, be supported by the PI3K/Akt/ACLY axis. Accordingly, ACLY knockdown reverses EMT and cancer stemness, especially by reducing Snail expression [87,88]. In line with this, citrate inhibits CSCs survival, and it reverses EMT in an in vivo lung cancer model, especially in conjunction with chemotherapy, as assessed by an increase in E-cadherin expression and a reduced expression of Vimentin and Snail [88]. In addition, it has been shown that citrate is able to induce cell death of cells showing the CSC phenotype CD44 high/CD24 low [77].

From a larger perspective, the metabolism of cancer cells is coupled with the cell cycle progression since some key metabolic enzymes are multifunctional enzymes, also acting as regulators of the cell cycle [93]. Particularly, PFKFB3, PKM2, and GAPDH periodically translocate to the nucleus during the cell cycle in order to regulate the expression of oncogenes or cell cycle regulators [38]. F-2,6-BP promotes G1/S phase transition, as it induces the degradation of the suppressor p27 [62]. In addition, GAPDH, which induces resistance to apoptosis, likely by promoting the overexpression of the key anti-apoptotic factor B-cell lymphoma-extra large (Bcl-xL) protein [94], accelerates cell cycle progression towards mitosis [95].

\section{The Central Place of Citrate in Cancer Cells Relying on Oxidative Metabolism}

\subsection{Cancer Cells Are Not Inherently Glycolytic}

In vitro studies have shown that numerous cancer cells do not rely mainly on the Warburg effect but predominantly on an oxidative or intermediate metabolism $[30,96,97]$. This has been especially observed in cells growing in lipid-rich environments (such as triple negative breast cancer cells or ovarian cancer cells developing in the peritoneum), as well as in cancer stem cells (CSCs) [31,98]. These cells produce energy mainly through FAO $[97,99]$, whose induction may be dependent on the activation of proliferator-activated 
receptor gamma coactivator 1-alpha (PGC1- $\alpha$ ) by acetylation $[100,101]$ and of adenosine monophosphate activated protein kinase (AMPK) [102]. Moreover, in aggressive cancer cells, it is not infrequent to observe the upregulation of mitochondrial enzymes, such as CS [103,104], or mitochondrial transporters, such as some translocases of the inner and outer mitochondrial membrane (TIMM and TOMM) [105]. Interestingly, the mitochondrial enzyme phosphoenolpyruvate carboxykinase (PCK2), which sustains gluconeogenesis, has been found to be more frequently upregulated in lung adenocarcinomas than in epidermoid tumors [58], and PCK2 expression is associated with a better prognosis compared to the expression of glycolytic expression of GLUT1 [58]. Of note, a metabolic cooperation can be established between hypoxic and non-hypoxic cancer cells in tumors, thus helping to spare glucose for the most glycolytic cells [106]. To achieve this regulation, lactate released by glycolytic cancer cells expressing MCT4 can be recycled by oxidative cells expressing MCT1. Here, lactate is converted into pyruvate by a reverse LDH-A reaction, and in turn pyruvate fuels the TCA cycle to produce energy and sustain biosynthesis $[107,108]$. In this setting, cancer cells chronically exposed to extracellular acidosis (due, for example, to excess protons secreted by glycolytic cancer cells that saturate bicarbonate buffer) would reprogram their metabolism, arresting glycolysis (proton $\mathrm{H}^{+}$is a well-known inhibitor of PFK1 [8,51]), and enhancing reductive carboxylation of glutamine sustaining FAS and promoting FAO [109]. The latter pathway provides acetyl-CoA for the functioning of the TCA cycle and for the acetylation of mitochondrial proteins, particularly of complex I, this process restraining ATP and ROS production [109]. Of note, citrate, OAA and malonate are well known inhibitors of succinate dehydrogenase (SDH) (or complex II), particularly in liver, brain, cardiac and muscle cells [110-112]. However, the modulation of SDH by these molecules in cancer cells remains to be studied.

Prostate cancer (PCa) (presumably the epithelial cancer with the most favourable prognosis), exhibits an oxidative metabolism [113], but may switch to the Warburg effect at the advanced metastatic stage [113]. FAO has been reported to be the dominant energetic pathway in PCa, which show a very low affinity for 2-deoxy-2-fluoro-D-glucose (FDG) (an indicator of glycolytic flux) in a positron emission tomography (PET) scan [114]. PCa cells promote $\mathrm{ACO} 2$ activity, favoring the oxidation of citrate in the TCA to produce energy (Figure 1). ACO2 upregulation has been identified as a key event in prostate carcinogenesis [113], a process promoted by a zinc deficiency due to the downregulation of the zinc transporter [115]. Accordingly, while the accumulation of zinc in benign prostate cells inhibits citrate oxidation and favours citrate accumulation in prostate tissue [113], lower levels of citrate, zinc, aspartate and spermine have been observed in PCa in comparison to non-cancer epithelium $[116,117]$.

\subsection{Citrate Constitutes a Driving Force also in Cells Relying on Oxidative Metabolism}

As we have seen, some cancer cells can engage glutamine oxidation and/or FAO to sustain energy production and their growth, particularly in a microenvironment lacking glucose and/or rich in lipids $[97,101]$, and/or submitted to chronically acidic $\mathrm{pH}$ conditions [109]. In this context, pyruvate carboxylase (PC), which is frequently upregulated, redirects the carbon flux (coming from glutaminolysis and/or FAO) towards gluconeogenesis providing the supply of precursors molecules for nucleotide synthesis [22,72]. Gluconeogenesis is the reverse pathway of glycolysis, which is physiologically activated (as showed in normal hepatocytes) by four enzymes: PC, PCK, fructose-1,6-bisphosphatase (FBPase), and glucose-6-phosphatase (G6Pase).

FAO sustains a high production of acetyl-CoA and/or of KBs (including acetone, which can feed gluconeogenesis). Acetyl-CoA (derived from FAO or KB degradation) is conjugated to OAA (produced by PC from pyruvate) to form citrate. The low affinity of ACO2 for citrate regulates the carbon flux in the TCA cycle, thus adapting ATP production to the cell requirements and avoiding its overproduction. The citrate, in excess, is exported out of mitochondria into the cytosol [42-45]. Here, citrate is converted back by ACLY into acetyl-CoA and OAA (Figure 1). The latter can sustain gluconeogenesis by conversion 
into phosphoenolpyruvate (PEP), a reaction catalysed by PCK, which has both a cytosolic isoform (PCK1) and a mitochondrial isoform (PCK2). While cytosolic PCK1 mainly converts citrate-derived OAA into PEP, mitochondrial PCK2 converts pyruvate-derived OAA (produced by PC) into PEP, which is further exported into the cytosol by a specific transporter [118]. Of note, mitochondrial OAA can be furnished by PC, but also by the recycling of cytosolic OAA (derived from citrate) converted back by MDH into malate, a molecule that can enter mitochondria.

Similarly to what is observed in normal cells, it is possible that the high cytosolic level of citrate-derived from FAO-promotes, in some cancer cells, the inactivation of glycolysis while concomitant gluconeogenesis is activated [7]. However, the upregulation of ACLY may prevent or attenuate this so-celled Randle cycle regulation, by inducing a continuous leak of citrate, which favours a truncated gluconeogenesis because FBPase is inactivated. Therefore, some of gluconeogenesis intermediates can be redirected towards the serine-methionine pathway and the non-oxidative PPP to sustain biosynthesis. As a result, a low citrate level would concomitantly promote futile cycles, gluconeogenesis and glycolysis, FAO and de novo FAS. Further studies are required to precisely establish the metabolism and regulation of oxidative cancer cells in various environmental conditions.

\section{The Possible Role of Citrate in the Metabolism of the Microenvironment}

There is a variety of non-cancerous cells in the TME, such as cancer-associated fibroblasts (CAFs), endothelial cells, macrophages, and immune cells. The latter have numerous subgroups, and schematically includes cells fighting cancer cells, such as cytotoxic CD ${ }^{+}$ $\mathrm{T}$ lymphocytes and pro-inflammatory M1 macrophages, and also cells promoting cancer development (i.e., pro-tumoral immune cells), such as myeloid-derived suppressor cells (MDSCs), regulatory T cells (Tregs), and M2 anti-inflammatory macrophages (for a review, see [119]). Cancer cells deprive TME of nutrients, particularly glucose and amino acids. At the same time, cancer cells can secrete different waste products (lactate, nitric oxide (NO), polyamines, adenosine, and $\mathrm{H}^{+}$), which can drive exhaustion (non-responsiveness) of M1 macrophages and cytotoxic T cells. Concomitantly, immunosuppressive cells, which preferentially rely on FAO, are activated [120-124]. Of note, hypoxia and HIF- $1 \alpha$ promote the formation of a fibrotic tumor stroma [125]. Lactate secreted by glycolytic CAFs (a process named "the reverse Warburg effect") can sustain the metabolism of oxidative cancer cells [126]. Thus, strategies targeting the recycling of waste products or redirecting nutrients towards cytotoxic immune cells appear as rational interventions to counteract the growth of cancer tumors [127]. Remarkably, peritoneal tumor xenografts in mice (B16 melanoma or ID8 ovarian carcinoma) promote glycolysis and FAO in peritoneal resident macrophages with a high mitochondrial production of itaconate [128]. Itaconate is a potent anti-inflammatory molecule derived from cis-aconitate, produced by the aconitate decarboxylase (ACOD) encoded by the immune-responsive gene-1 (Irg1) [129]. In tumors, the mechanisms by which aconitate production is enhanced and by which it promotes tumor growth are still not clear and warrant further investigation.

The citrate available in the TME appears to be essential to support cancer cell growth. As we have seen, in cancer cells, citrate is generated by the activity of the CS and/or the carboxylation of AKG (especially in cells with dysfunctional OXPHOS or TCA cycle) [39]. However, several experiments have made it possible to estimate that up to one third of the total intracellular citrate pool in cancer cells may also be derived from the direct uptake of extracellular citrate, a process promoted further by glucose deprivation [130]. Experimental studies showed that physiological concentration of citrate $(200 \mu \mathrm{M})$ can sustain the proliferation of various cancer cells, such as prostate, pancreatic and gastric ones $[130,131]$. Interestingly, citrate concentrations of up to $5 \mathrm{mM}$ can stimulate lipid synthesis and histone acetylation in HepG2 cells, but higher concentrations (10 mM or more) decreased both acetylation and ACLY expression [132]. Factors influencing the blood concentration of citrate (which is normally around 100-150 $\mu \mathrm{M}$ [133]) have not been well characterized up to now. In theory, it likely depends on the daily intake, the secretion of 
citrate by body reserves (approximately $90 \%$ of citrate is located in mineralized tissues), and the citrate consumption in various biological processes, particularly bone formation [134].

\section{The Anti-Cancer Effects of Citrate at High Dosages in Preclinical Experiments}

\subsection{In Vitro Studies}

In various cell lines, a high concentration of citrate-generally above $10 \mathrm{mM}$-inhibits the proliferation of cancer cells in a dose dependent manner. As showed in Table 1, this anti-cancer effect involves various mechanisms such as the inactivation of PFK1, the inhibition of glycolysis and ATP production, and the stimulation of apoptotic cell death by various processes (in particular, the activation of pro-apoptotic proteins and various caspases $(2,3,8$, and 9), and the decreased expression of the two key anti-apoptotic factors, Bcl-xL and Mcl-1 [75,76]). Of note, the levels of glucose-derived citrate are decreased by approximately $25 \%$ in Bcl-xL-expressing cells compared to control ones [135], and the addition of citrate to these cells leads to increased protein $\mathrm{N}$ - $\alpha$-acetylation and sensitization to apoptosis [135]. Importantly, citrate at high concentration (10 mM) also inhibits the insulin-like growth factor-1 receptor (IGF-1R) pathway, which promotes the downstream activation of $\mathrm{PI} 3 \mathrm{~K} / \mathrm{Akt} / \mathrm{mTOR}$ and MAPK pathways [77]. In addition, a high dose of citrate activates PTEN, the key phosphatase inhibiting the PI3K/Akt pathway [77,78]. Furthermore, citrate increases the sensibility of cells to chemotherapy (in particular, cisplatin) and to Bcl-xL inhibitors (ABT 737 or siXL1), also increasing the levels of interleukin-1 $\beta$, interleukin-8 and tumor necrosis factor (TNF).

Table 1. Literature review of the main studies describing the effects of citrate $(\geq 10 \mathrm{mM})$ on cancer cells.

\begin{tabular}{|c|c|c|c|c|c|}
\hline Cells & Cancer Type & $\begin{array}{l}\text { In Vivo/ } \\
\text { In Vitro }\end{array}$ & Citrate Targets/Citrate Effects on Cells & Year & Ref. \\
\hline MSTO-211H cells & Mesothelioma cells & In vitro & $\begin{array}{l}\text { Decreased expression of anti-apoptotic protein } \\
\text { Mcl- } 1 \text { and Bcl-xL. Depletion of ATP. } \\
\text { Increase in the cisplatin antitumor effect. }\end{array}$ & 2009 & [25] \\
\hline B16 cells & Murine melanoma & In vitro & $\begin{array}{l}\text { Combined treatment with UVB increases c-Jun and p38 } \\
\text { phosphorylation and the activity of caspase- } 3 \text { and }-9 \text {. }\end{array}$ & 2009 & [136] \\
\hline HeLa cells & Adenocarcinoma & In vitro & $\begin{array}{l}\text { Increase in the protein } \mathrm{N} \text {-alpha-acetylation. } \\
\text { Sensitivity to apoptotic stimuli. }\end{array}$ & 2011 & [135] \\
\hline $\begin{array}{l}\text { BGC-823 cells } \\
\text { SGC-7901 cells }\end{array}$ & Gastric cancer & In vitro & Decreased expression of anti-apoptotic protein Mcl-1. & 2011 & [26] \\
\hline $\begin{array}{c}\text { Tet21N cells } \\
\text { SKNAS cells } \\
\text { SKNSH cells } \\
\text { SK-N-BE }(2) \text { cells } \\
\text { U1810 cells }\end{array}$ & $\begin{array}{c}\text { Neuroblastoma } \\
\text { Neuroblastoma } \\
\text { Neuroblastoma } \\
\text { Neuroblastoma } \\
\text { Lung cancer }\end{array}$ & In vitro & $\begin{array}{l}\text { Activation of the apical caspases- } 8 \text { and }-2 \text {. } \\
\text { Increased release of the cytochrome C. }\end{array}$ & 2012 & [137] \\
\hline C6 cells & Glioblastoma & In vitro & $\begin{array}{l}\text { Inhibition of the number of vascular branching points. } \\
\text { Inhibition of the length of vascular tubules. } \\
\text { Inhibition of angiogenesis. }\end{array}$ & 2012 & [138] \\
\hline $\begin{array}{c}\text { SKOV3 cells } \\
\text { IGROV1-R10 cells }\end{array}$ & Ovarian cancer & In vitro & $\begin{array}{l}\text { Decreased expression of the anti-apoptotic protein Mcl-1. } \\
\text { Increase in the efficacy of ABT } 737 \text { treatment. }\end{array}$ & 2013 & [27] \\
\hline U937 cells & $\begin{array}{l}\text { Acute Monocytic } \\
\text { Leukemia }\end{array}$ & In vitro & $\begin{array}{l}\text { Increase in caspase- } 3 \text { and }-9 \text { activities. } \\
\text { Decreased expression of anti-apoptotic protein Bcl-2. }\end{array}$ & 2013 & [139] \\
\hline MGC-803 cells & Gastric cancer & In vitro & $\begin{array}{c}\text { Increased expression of the pro-apoptotic protein Bax. } \\
\text { Inhibition of the PFK activity. } \\
\text { Decrease in lactate and ATP production. }\end{array}$ & 2016 & [76] \\
\hline SGC-7901 cells & Gastric cancer & $\begin{array}{l}\text { In vitro and } \\
\text { in vivo }\end{array}$ & $\begin{array}{l}\text { Inhibition of the PFK1 activity. } \\
\text { Decreased tumor growth and increased apoptosis (increased } \\
\text { cytC release and Bax expression, reduced Bcl-2). }\end{array}$ & 2016 & [75] \\
\hline $\begin{array}{c}\text { A549 cells } \\
\text { Pan02 cells } \\
\text { Her2/Neu model }\end{array}$ & $\begin{array}{l}\text { Lung cancer } \\
\text { Pancreatic cancer } \\
\text { Breast cancer } \\
\text { model }\end{array}$ & $\begin{array}{l}\text { In vitro and } \\
\text { in vivo }\end{array}$ & $\begin{array}{l}\text { Inhibition of IGF-1R/AKT pathway via PTEN. } \\
\text { Inhibition of tumor growth in Ras-driven lung cancer, Pan02 } \\
\text { xenograft and Her2/Neu models. }\end{array}$ & 2017 & [77] \\
\hline EC109 cells & $\begin{array}{l}\text { Oesophageal } \\
\text { cancer }\end{array}$ & In vitro & Increase in apoptosis. & 2017 & [140] \\
\hline
\end{tabular}


Table 1. Cont

\begin{tabular}{ccccccc}
\hline Cells & Cancer Type & $\begin{array}{c}\text { In Vivo/ } \\
\text { In Vitro }\end{array}$ & Citrate Targets/Citrate Effects on Cells & Year & Ref. \\
\hline AGS cells & Gastric cancer & In vitro & $\begin{array}{c}\text { Increase in the levels of interleukin-1 } \beta \text {, IL-8 and TNF. } \\
\text { Increased activity of caspase-3 and -9. }\end{array}$ & 2018 & [141] \\
\hline $\begin{array}{c}\text { HOS \& LM8 cells } \\
\text { HT1080 cells }\end{array}$ & $\begin{array}{c}\text { Osteosarcoma } \\
\text { Fibrosarcoma }\end{array}$ & $\begin{array}{c}\text { In vitro and } \\
\text { in vivo }\end{array}$ & Enhancement of cisplatin anti-tumor effect. & 2019 & [142] \\
\hline PSC cells & $\begin{array}{c}\text { Pharyngeal } \\
\text { carcinoma }\end{array}$ & In vitro & $\begin{array}{c}\text { Cell cycle arrest at the G2/M phase. } \\
\text { Stabilization of cyclinB1-CDK1 through p85 } \alpha \text {-PTEN. }\end{array}$ & 2019 & [78] \\
\hline MCF-7 cells & Breast cancer & In vitro & Increase in the efficacy of radiation therapy. & 2020 & [143] \\
\hline HMV-II cells & Melanoma & In vitro & $\begin{array}{c}\text { Inhibition of cancer cell proliferation. } \\
\text { Reduction in } \beta \text {-catenin levels. }\end{array}$ & 2020 & [144] \\
\hline HepG2 cells & Hepatoma & In vitro & $\begin{array}{c}\text { Inhibition of the ACLY-mediated H4 acetylation and } \\
\text { lipid deposition. }\end{array}$ & 2020 & [132] \\
\hline PCa cells & Prostate cancer & $\begin{array}{c}\text { In vitro and } \\
\text { in vivo }\end{array}$ & $\begin{array}{c}\text { Induction of cell death through autophagy modulation. } \\
\text { Inhibition of tumor growth in a xenograft model. }\end{array}$ & 2021 & [145] \\
\hline Panc-1 cells & Pancreatic cancer & In vivo & $\begin{array}{c}\text { Potentiation of anti-tumor effect of 5-FU derivative. } \\
\text { Reduction in tumor growth (xenograft model). }\end{array}$ & 2021 & [146] \\
\hline
\end{tabular}

\subsection{In Vivo Studies}

Citrate inhibits the growth of several xenograft cancer models in mice, increasing the response to chemotherapy. Indeed, daily intra-peritoneal (i.p.) injection of sodium citrate for 4 weeks ( 15 to $30 \mathrm{mg} / \mathrm{kg} /$ day) reduced tumor development in a gastric cancer model (SGC-7901 cells in nude mice), partly by promoting tumor apoptosis [75]. Similarly, in murine tumor models of human osteosarcoma and fibrosarcoma, i.p. injections (two times per week) of citrate (50 to $100 \mathrm{mg} / \mathrm{kg}$ ), caffeine (50 to $100 \mathrm{mg} / \mathrm{kg}$ ), and caffeine citrate (100 to $200 \mathrm{mg} / \mathrm{kg}$ ) reduced tumor growth (with caffeine citrate showing the stronger effect), and all molecules potentiated the anti-tumoral effect of cisplatin treatment [142]. Oral citrate administration also impacts tumor growth. Indeed, oral gavage of citrate sodium ( $4 \mathrm{~g} / \mathrm{kg}$ twice a day) for several weeks (4 to 7 weeks) significantly regressed tumors in various murine models, such as subcutaneously implanted syngeneic pancreatic tumor (Pan02), human lung adenocarcinoma (A549 cells) xenografts in nude mice, Rasdriven lung cancer in genetically engineered mouse (GEM), and breast cancer driven by human epidermal growth factor receptor 2/(Her2/Neu) in GEM [77]. Regression of tumors was frequently associated with differentiation and abundant leukocyte infiltration, predominantly constituted of T lymphocytes. Interestingly, plasma citrate levels of these chronically citrate-treated mice were approximately $3 \mathrm{mM}$, roughly eight times higher than the ones recorded for non-citrate treated mice [77]. A recent study showed that citrate also suppresses growth of PCa xenograft tumors in mice [145]. Of note, in a pancreatic cancer-xenograft murine model, 14 daily doses $(500 \mathrm{mg} / \mathrm{kg} /$ day) of oral citrate induced the neutralization of TME acidity and potentiated the therapeutic effect of an oral administration of active 5-fluoro-uracil derivative [146].

\section{Discussion and Therapeutic Perspectives}

In sum, the central role of citrate in the metabolism of cancer cells, which we first outlined some years ago [1], has been confirmed by various studies [147,148]. Indeed, citrate provides acetyl-CoA (supporting various processes such as protein acetylation regulating enzyme activities, histone acetylation regulating gene expression, and lipid synthesis required for membrane formation) and also OAA (which can sustain biosynthesis or supply energy through TCA cycle coupled with OXPHOS). In addition, contrary to what was observed in normal cells, in cancer cells, the upregulation of ACLY concurs to maintain a low cytosolic level of citrate, favoring further the enhancement of glycolysis (which would be inhibited by high citrate) and the activation of oncogenic drivers, such as the PI3K/Akt and WNT/ $\beta$-catenin pathway, which promotes aggressiveness, 
EMT and de-differentiation $[77,87,91,144,145,149]$. As we have seen, we proposed that the impediment of the negative feedback exercised by citrate on PFK1 and PFK2 is an essential factor of the Warburg effect functioning, allowing high production of F-1,6-BP. This high production promotes Ras/PI3K/Akt signaling [67-69], which in turn activates both PFK2/PFKFB3 $[62,150]$ and HIF-1 $\alpha$ [151], further supporting glycolysis. Moreover, PI3K/Akt downregulates the TCA cycle coupled with OXPHOS functioning [73], and F-1,6-BP directly inhibits OXPHOS [40]. At the same time, ACLY activity is enhanced by Akt $[82,83]$ and phosphorylated sugars [84].

Although the specific effects of citrate on all the different cell types populating the TME remains to be studied, we suggest that immunosuppressive cells, which preferentially rely on FAO [120,123,124], could release citrate at physiologic concentrations in the TME, thus sustaining cancer cell growth. Of note, these immunosuppressive cells may recycle the lactate secreted by tumor cells or CAFs [126]. This could create a metabolic cooperation between immunosuppressive cells and cancer cells, since lactate excreted by cancer cells would sustain the secretion of citrate by immunosuppressive cells, these cells also secreting itaconate promoting cancer growth. Further in vitro studies could help to clarify the impact of these putative cycles on cancer growth. The development of new biological methods and imaging techniques, allowing the measurement of molecule concentrations in tumors, would help in analysing these possible metabolic adaptations in the TME.

From a therapeutic perspective, two strategies have been proposed to target citrate metabolism. In the first, citrate uptake by cancer cells could be blocked by inhibiting the membrane transporter $\mathrm{pmCiC}$ (a specific transporter mediating citrate uptake by cancer cells), specifically by using gluconate. This strategy efficiently counteracted tumor growth in a human pancreatic xenograft murine model [130]. In the second (that we proposed), cancer cells and TME could be flooded by high concentration of citrate (30 to 50 times the physiological level), with the objective of inhibiting glycolysis in glycolytic cancer cells by various mechanisms that have previously been described, likely based on the increase in cytosolic citrate level promoting PFK and glycolysis inhibition. As we have stated, dichloroacetate, which inhibits PDK1 and restores drug sensitivity in paclitaxel-resistant lung cancer cells (A549), increases cytosolic citrate [28], while ACLY inhibition, which reduces tumor growth in various models, likely increases citrate level [87]. Furthermore, sodium citrate is also a basic salt, which similarly to bicarbonate, may buffer acidity in TME. This effect favours the penetration of chemotherapy drugs (such as doxorubicin) in cancer cells, also improving the efficacy of mTORC1 inhibitors (rapamycin), and the response to immunotherapies [152-154]. The buffering of extracellular acidity could also counteract cancer cells relying on oxidative metabolism, in particular FAO, which is promoted in cancer cells by chronic acidity [109].

As Mycielska and Geissler commented [155] 'both the "low" and "high" citrate uptake approaches do make sense'. We agree that strategies altering the intracellular citrate levels in either direction should be further explored. Short cycles of "metabolic interventions" targeting citrate may appear preferable compared to prolonged interventions, since the metabolism of various cancer cells is plastic, and some clone cells could adapt drugs or metabolic inhibitory strategies, shifting, for example, from a glycolytic to an oxidative metabolism (and vice versa) or bypassing the inhibition of a chronically administered strategy. In this setting, an in vitro study reported the occurrence of a resistant clone of metastatic PCa cancer cells (PC3) under prolonged $10 \mathrm{mM}$ citrate exposure (more than two weeks). This process was associated with a shorter PKF1 form (insensible to citrate regulation) and with the upregulation of autophagy [156]. Of note, this survival processrecycling superfluous molecules (proteins and lipids)—requires functional mitochondria for ATP production derived from FAO [157]. However, the effects of citrate on PCa are controversial, taking into account that a recent study reported that citrate activates autophagic cell death via downregulation of the Akt/mTOR pathway, also suppressing growth of $\mathrm{PCa}$ xenograft tumors in mice [145]. Additionally, a prolonged inhibition of pmCiC could be bypassed by increasing the uptake of acetate, which is another source of acetyl-CoA [158], 
or by producing acetyl-CoA directly from glycolysis through transketolase-like 1 activity [159]. While waiting for new methods assessing the metabolism of a specific tumor in vivo and its vulnerabilities for personalized specific inhibitions, we think that the citrate strategy we proposed should be tested during brief periods to increase the sensibility or response to cytotoxic treatments including new anti-cancer therapies.

For clinical tests, it should be mentioned that citrate has a very low toxicity (see "citrate" PubChem CID 311, at https:/ / pubchem.ncbi.nlm.nih.gov/, accessed on 17 June 2021), as confirmed also by in vivo studies [145], because it is an endogenous metabolite with a complete and rapid metabolism, and thus a very short half-life [160]. However, if administrated in excess, citrate could cause hypocalcaemia, muscle spasms, convulsions, and also a risk of haemorrhage due to its chelating properties of calcium and other divalent cations. These effects can be treated urgently and at best prevented by administration of calcium chloride. By extrapolating the results of a preclinical model [77], the active dose in man would be likely much lower than the one inducing the adverse effects. Clinical trials should determine the mode and duration of citrate sodium administration, its toxicity, and its efficiency. Knowing that numerous patients worldwide have incurable cancers supported by aerobic glycolysis and key oncogenic drivers (such as IGF-1R, Ras/PI3K/Akt, HER2/neu, WNT/ $\beta$-catenin, TME acidity and EMT) $[145,161,162]$, all pathways efficiently counteracted by citrate sodium in preclinical studies, we strongly believe that the citrate strategy we have proposed since many years [25] should now be considered for clinical trials. In particular, this strategy could increase both the sensitivity to standard chemotherapy drugs and to targeted therapies, whose resistance is mainly supported by the Warburg effect and its oncogenic drivers.

Author Contributions: P.I. designed and wrote the manuscript. L.S. and A.C. contributed to the writing and editing of the manuscript. L.S., Z.W. and H.L. prepared the figures and table. J.G., D.F. and L.F. contributed to the revision of the manuscript and discussion related to the testing of citrate in trials. All authors have read and agreed to the published version of the manuscript.

Funding: L.S. was supported by a fellowship from Fondation ARC (ARCPDF22020010001123).

Conflicts of Interest: The authors have no conflict of interest to declare.

\section{References}

1. Icard, P.; Poulain, L.; Lincet, H. Understanding the central role of citrate in the metabolism of cancer cells. Biochim. Biophys. Acta Rev. Cancer 2012, 1825, 111-116. [CrossRef] [PubMed]

2. Nelson, D.; Cox, M. Lehninger Principles of Biochemistry; W.H. Freeman \& Co Ltd.: New York, NY, USA, 2021; ISBN 9781319228002.

3. Nissler, K.; Petermann, H.; Wenz, I.; Brox, D. Fructose 2,6-bisphosphate metabolism in Ehrlich ascites tumour cells. J. Cancer Res. Clin. Oncol. 1995, 121, 739-745. [CrossRef]

4. Icard, P.; Fournel, L.; Coquerel, A.; Gligorov, J.; Alifano, M.; Lincet, H. Citrate targets FBPase and constitutes an emerging novel approach for cancer therapy. Cancer Cell Int. 2018, 18, 175. [CrossRef]

5. Cahill, G.F. Starvation in man. Clin. Endocrinol. Metab. 1976, 5, 397-415. [CrossRef]

6. Rui, L. Energy Metabolism in the Liver. In Comprehensive Physiology; John Wiley \& Sons, Inc.: Hoboken, NJ, USA, 2014; Volume 4, pp. 177-197.

7. Hue, L.; Taegtmeyer, H. The Randle cycle revisited: A new head for an old hat. Am. J. Physiol. Metab. 2009, 297, E578-E591. [CrossRef]

8. Berg, J.; Tymoczko, J.; Gatto, G.; Stryer, L. Biochemistry, 9th ed.; W.H. Freeman: New York, NY, USA, 2019; ISBN 978-1319114657.

9. Brun, T.; Roche, E.; Assimacopoulos-Jeannet, F.; Corkey, B.E.; Kim, K.-H.; Prentki, M. Evidence for an Anaplerotic/Malonyl-CoA Pathway in Pancreatic-Cell Nutrient Signaling. Diabetes 1996, 45, 190-198. [CrossRef]

10. Costello, L.C.; Franklin, R.B. Citrate metabolism of normal and malignant prostate epithelial cells. Urology 1997, 50, 3-12. [CrossRef]

11. Costello, L.C.; Franklin, R.B.; Reynolds, M.A. The Important Role and Implications of Citrate in the Composition, Structure, and Function of Oral/Periodontal/Craniofacial Tissues. Madridge J. Dent. Oral Surg. 2018, 3, 85-90. [CrossRef] [PubMed]

12. Costello, L.C.; Chellaiah, M.; Zou, J.; Franklin, R.B.; Reynolds, M.A. The status of citrate in the hydroxyapatite/collagen complex of bone; and Its role in bone formation. J. Regen. Med. Tissue Eng. 2014, 3, 4. [CrossRef]

13. O'Neill, L.A.J.; Pearce, E.J. Immunometabolism governs dendritic cell and macrophage function. J. Exp. Med. 2016, 213, 15-23. [CrossRef] 
14. Williams, N.C.; O’Neill, L.A.J. A Role for the Krebs Cycle Intermediate Citrate in Metabolic Reprogramming in Innate Immunity and Inflammation. Front. Immunol. 2018, 9, 141. [CrossRef]

15. Abdel-Salam, O.M.E.; Youness, E.R.; Mohammed, N.A.; Morsy, S.M.Y.; Omara, E.A.; Sleem, A.A. Citric Acid Effects on Brain and Liver Oxidative Stress in Lipopolysaccharide-Treated Mice. J. Med. Food 2014, 17, 588-598. [CrossRef]

16. He, W.; Heinz, A.; Jahn, D.; Hiller, K. Complexity of macrophage metabolism in infection. Curr. Opin. Biotechnol. 2021, 68, 231-239. [CrossRef]

17. Infantino, V.; Pierri, C.L.; Iacobazzi, V. Metabolic Routes in Inflammation: The Citrate Pathway and its Potential as Therapeutic Target. Curr. Med. Chem. 2020, 26, 7104-7116. [CrossRef] [PubMed]

18. Mller, A.J.; Call, J.E.; Whiting, R.C. Comparison of Organic Acid Salts for Clostridium botulinum Control in an Uncured Turkey Product. J. Food Prot. 1993, 56, 958-962. [CrossRef] [PubMed]

19. Lee, Y.; Cesario, T.; Owens, J.; Shanbrom, E.; Thrupp, L.D. Antibacterial activity of citrate and acetate. Nutrition 2002, 18, 665-666. [CrossRef]

20. Lee, Y.-L.; Thrupp, L.; Owens, J.; Cesario, T.; Shanbrom, E. Bactericidal activity of citrate against Gram-positive cocci. Lett. Appl. Microbiol. 2001, 33, 349-351. [CrossRef]

21. Icard, P.; Shulman, S.; Farhat, D.; Steyaert, J.-M.; Alifano, M.; Lincet, H. How the Warburg effect supports aggressiveness and drug resistance of cancer cells? Drug Resist. Update 2018, 38, 1-11. [CrossRef]

22. Icard, P.; Wu, Z.; Alifano, M.; Fournel, L. Gluconeogenesis of Cancer Cells Is Disrupted by Citrate. Trends Cancer 2019, 5, 265-266. [CrossRef] [PubMed]

23. Warburg, O. On the origin of cancer cells. Science 1956, 123, 309-314. [CrossRef]

24. Salas, M.L.; Viñuela, E.; Salas, M.; Sols, A. Citrate inhibition of phosphofructokinase and the Pasteur effect. Biochem. Biophys. Res. Commun. 1965, 19, 371-376. [CrossRef]

25. Zhang, X.; Varin, E.; Allouche, S.; Lu, Y.; Poulain, L.; Icard, P. Effect of Citrate on Malignant Pleural Mesothelioma Cells: A Synergistic Effect with Cisplatin. Anticancer Res. 2009, 29, 1249-1254. [PubMed]

26. Lu, Y.; Zhang, X.; Zhang, H.; Lan, J.; Huang, G.; Varin, E.; Lincet, H.; Poulain, L.; Icard, P. Citrate induces apoptotic cell death: A promising way to treat gastric carcinoma? Anticancer Res. 2011, 31, 797-805. [PubMed]

27. Lincet, H.; Kafara, P.; Giffard, F.; Abeilard-Lemoisson, E.; Duval, M.; Louis, M.-H.; Poulain, L.; Icard, P. Inhibition of Mcl-1 expression by citrate enhances the effect of Bcl-xL inhibitors on human ovarian carcinoma cells. J. Ovarian Res. $2013,6,72$. [CrossRef]

28. Zhou, X.; Chen, R.; Yu, Z.; Li, R.; Li, J.; Zhao, X.; Song, S.; Liu, J.; Huang, G. Dichloroacetate restores drug sensitivity in paclitaxel-resistant cells by inducing citric acid accumulation. Mol. Cancer 2015, 14, 63. [CrossRef]

29. Tomasetti, M.; Nocchi, L.; Staffolani, S.; Manzella, N.; Amati, M.; Goodwin, J.; Kluckova, K.; Nguyen, M.; Strafella, E.; Bajzikova, M.; et al. MicroRNA-126 Suppresses Mesothelioma Malignancy by Targeting IRS1 and Interfering with the Mitochondrial Function. Antioxid. Redox Signal. 2014, 21, 2109-2125. [CrossRef]

30. Zu, X.L.; Guppy, M. Cancer metabolism: Facts, fantasy, and fiction. Biochem. Biophys. Res. Commun. 2004, 313, 459-465. [CrossRef]

31. Peiris-Pagès, M.; Martinez-Outschoorn, U.E.; Pestell, R.G.; Sotgia, F.; Lisanti, M.P. Cancer stem cell metabolism. Breast Cancer Res. 2016, 18, 55. [CrossRef] [PubMed]

32. McGarry, J.D.; Takabayashi, Y.; Foster, D.W. The role of malonyl-CoA in the coordination of fatty acid synthesis and oxidation in isolated rat hepatocytes. J. Biol. Chem. 1978, 253, 8294-8300. [CrossRef]

33. DeBerardinis, R.J.; Chandel, N.S. Fundamentals of cancer metabolism. Sci. Adv. 2016, 2, e1600200. [CrossRef]

34. Martinez-Outschoorn, U.E.; Peiris-Pagés, M.; Pestell, R.G.; Sotgia, F.; Lisanti, M.P. Cancer metabolism: A therapeutic perspective. Nat. Rev. Clin. Oncol. 2017, 14, 11-31. [CrossRef]

35. Heiden, M.G.V.; Cantley, L.C.; Thompson, C.B. Understanding the warburg effect: The metabolic requirements of cell proliferation. Science 2009, 324, 1029-1033. [CrossRef]

36. Zhao, S.; Xu, W.; Jiang, W.; Yu, W.; Lin, Y.; Zhang, T.; Yao, J.; Zhou, L.; Zeng, Y.; Li, H.; et al. Regulation of Cellular Metabolism by Protein Lysine Acetylation. Science 2010, 327, 1000-1004. [CrossRef]

37. Lv, L.; Li, D.; Zhao, D.; Lin, R.; Chu, Y.; Zhang, H.; Zha, Z.; Liu, Y.; Li, Z.; Xu, Y.; et al. Acetylation Targets the M2 Isoform of Pyruvate Kinase for Degradation through Chaperone-Mediated Autophagy and Promotes Tumor Growth. Mol. Cell 2011, 42, 719-730. [CrossRef] [PubMed]

38. Icard, P.; Fournel, L.; Wu, Z.; Alifano, M.; Lincet, H. Interconnection between Metabolism and Cell Cycle in Cancer. Trends Biochem. Sci. 2019, 44, 490-501. [CrossRef]

39. Mullen, A.R.; Wheaton, W.W.; Jin, E.S.; Chen, P.-H.; Sullivan, L.B.; Cheng, T.; Yang, Y.; Linehan, W.M.; Chandel, N.S.; DeBerardinis, R.J. Reductive carboxylation supports growth in tumour cells with defective mitochondria. Nature 2012, 481, 385-388. [CrossRef]

40. Díaz-Ruiz, R.; Avéret, N.; Araiza, D.; Pinson, B.; Uribe-Carvajal, S.; Devin, A.; Rigoulet, M. Mitochondrial Oxidative Phosphorylation Is Regulated by Fructose 1,6-Bisphosphate. J. Biol. Chem. 2008, 283, 26948-26955. [CrossRef] [PubMed]

41. Costello, L.C.; Liu, Y.; Zou, J.; Franklin, R.B. Mitochondrial aconitase gene expression is regulated by testosterone and prolactin in prostate epithelial cells. Prostate 2000, 42, 196-202. [CrossRef]

42. Tong, W.-H.; Rouault, T.A. Metabolic regulation of citrate and iron by aconitases: Role of iron-sulfur cluster biogenesis. BioMetals 2007, 20, 549-564. [CrossRef] [PubMed] 
43. Lushchak, O.V.; Piroddi, M.; Galli, F.; Lushchak, V.I. Aconitase post-translational modification as a key in linkage between Krebs cycle, iron homeostasis, redox signaling, and metabolism of reactive oxygen species. Redox Rep. 2014, 19, 8-15. [CrossRef] [PubMed]

44. Lin, G.; Brownsey, R.W.; MacLeod, K.M. Regulation of mitochondrial aconitase by phosphorylation in diabetic rat heart. Cell. Mol. Life Sci. 2009, 66, 919-932. [CrossRef]

45. Palmieri, E.M.; Gonzalez-Cotto, M.; Baseler, W.A.; Davies, L.C.; Ghesquière, B.; Maio, N.; Rice, C.M.; Rouault, T.A.; Cassel, T.; Higashi, R.M.; et al. Nitric oxide orchestrates metabolic rewiring in M1 macrophages by targeting aconitase 2 and pyruvate dehydrogenase. Nat. Commun. 2020, 11, 698. [CrossRef]

46. Keohavong, P.; Kat, A.G.; Cariello, N.F.; Thilly, W.G. DNA Amplification In Vitro Using T4 DNA Polymerase. DNA 1988, 7, 63-70. [CrossRef]

47. Marin-Hernandez, A.; Gallardo-Perez, J.; Ralph, S.; Rodriguez-Enriquez, S.; Moreno-Sanchez, R. HIF-1 $\alpha$ Modulates Energy Metabolism in Cancer Cells by Inducing Over-Expression of Specific Glycolytic Isoforms. Mini Rev. Med. Chem. 2009, 9, 1084-1101. [CrossRef] [PubMed]

48. Kim, J.; Tchernyshyov, I.; Semenza, G.L.; Dang, C.V. HIF-1-mediated expression of pyruvate dehydrogenase kinase: A metabolic switch required for cellular adaptation to hypoxia. Cell Metab. 2006, 3, 177-185. [CrossRef] [PubMed]

49. Dhup, S.; Kumar Dadhich, R.; Ettore Porporato, P.; Sonveaux, P. Multiple Biological Activities of Lactic Acid in Cancer: Influences on Tumor Growth, Angiogenesis and Metastasis. Curr. Pharm. Des. 2012, 18, 1319-1330. [CrossRef]

50. Husain, Z.; Huang, Y.; Seth, P.; Sukhatme, V.P. Tumor-Derived Lactate Modifies Antitumor Immune Response: Effect on Myeloid-Derived Suppressor Cells and NK Cells. J. Immunol. 2013, 191, 1486-1495. [CrossRef] [PubMed]

51. Trivedi, B.; Danforth, W.H. Effect of pH on the kinetics of frog muscle phosphofructokinase. J. Biol. Chem. 1966, 241, 4110-4114. [CrossRef]

52. Rodic, S.; Vincent, M.D. Reactive oxygen species (ROS) are a key determinant of cancer's metabolic phenotype. Int. J. Cancer 2018, 142, 440-448. [CrossRef]

53. Chen, J.-Q.Q.; Russo, J. Dysregulation of glucose transport, glycolysis, TCA cycle and glutaminolysis by oncogenes and tumor suppressors in cancer cells. Biochim. Biophys. Acta Rev. Cancer 2012, 1826, 370-384. [CrossRef]

54. Cairns, R.A. Drivers of the Warburg Phenotype. Cancer J. 2015, 21, 56-61. [CrossRef]

55. Wise, D.R.; Deberardinis, R.J.; Mancuso, A.; Sayed, N.; Zhang, X.Y.; Pfeiffer, H.K.; Nissim, I.; Daikhin, E.; Yudkoff, M.; McMahon, S.B.; et al. Myc regulates a transcriptional program that stimulates mitochondrial glutaminolysis and leads to glutamine addiction. Proc. Natl. Acad. Sci. USA 2008, 105, 18782-18787. [CrossRef]

56. Lin, C.C.; Cheng, T.L.; Tsai, W.H.; Tsai, H.J.; Hu, K.H.; Chang, H.C.; Yeh, C.W.; Chen, Y.C.; Liao, C.C.; Chang, W.T. Loss of the respiratory enzyme citrate synthase directly links the Warburg effect to tumor malignancy. Sci. Rep. 2012, 2, 785. [CrossRef]

57. Na, F.; Wang, J.; Li, C.; Deng, L.; Xue, J.; Lu, Y. Primary Tumor Standardized Uptake Value Measured on F18-Fluorodeoxyglucose Positron Emission Tomography Is of Prediction Value for Survival and Local Control in Non-Small-Cell Lung Cancer Receiving Radiotherapy: Meta-Analysis. J. Thorac. Oncol. 2014, 9, 834-842. [CrossRef] [PubMed]

58. Smolle, E.; Leko, P.; Stacher-Priehse, E.; Brcic, L.; El-Heliebi, A.; Hofmann, L.; Quehenberger, F.; Hrzenjak, A.; Popper, H.H.; Olschewski, H.; et al. Distribution and prognostic significance of gluconeogenesis and glycolysis in lung cancer. Mol. Oncol. 2020, 14, 2853-2867. [CrossRef] [PubMed]

59. Hudson, C.D.; Hagemann, T.; Mather, S.J.; Avril, N. Resistance to the tyrosine kinase inhibitor axitinib is associated with increased glucose metabolism in pancreatic adenocarcinoma. Cell Death Dis. 2014, 5, e1160. [CrossRef]

60. Rotow, J.; Bivona, T.G. Understanding and targeting resistance mechanisms in NSCLC. Nat. Rev. Cancer 2017, 17, 637-658. [CrossRef]

61. Crochet, R.B.; Kim, J.D.; Lee, H.; Yim, Y.S.; Kim, S.G.; Neau, D.; Lee, Y.H. Crystal structure of heart 6-phosphofructo-2kinase/fructose-2,6-bisphosphatase (PFKFB2) and the inhibitory influence of citrate on substrate binding. Proteins Struct. Funct. Bioinform. 2017, 85, 117-124. [CrossRef]

62. Yalcin, A.; Clem, B.F.; Imbert-Fernandez, Y.; Ozcan, S.C.; Peker, S.; O’Neal, J.; Klarer, A.C.; Clem, A.L.; Telang, S.; Chesney, J. 6Phosphofructo-2-kinase (PFKFB3) promotes cell cycle progression and suppresses apoptosis via Cdk1-mediated phosphorylation of p27. Cell Death Dis. 2014, 5, e1337. [CrossRef] [PubMed]

63. Houddane, A.; Bultot, L.; Novellasdemunt, L.; Johanns, M.; Gueuning, M.-A.; Vertommen, D.; Coulie, P.G.; Bartrons, R.; Hue, L.; Rider, M.H. Role of Akt/PKB and PFKFB isoenzymes in the control of glycolysis, cell proliferation and protein synthesis in mitogen-stimulated thymocytes. Cell Signal. 2017, 34, 23-37. [CrossRef] [PubMed]

64. Jurica, M.S.; Mesecar, A.; Heath, P.J.; Shi, W.; Nowak, T.; Stoddard, B.L. The allosteric regulation of pyruvate kinase by fructose1,6-bisphosphate. Structure 1998, 6, 195-210. [CrossRef]

65. Ashizawa, K.; Willingham, M.C.; Liang, C.M.; Cheng, S.Y. In vivo regulation of monomer-tetramer conversion of pyruvate kinase subtype M2 by glucose is mediated via fructose 1,6-bisphosphate. J. Biol. Chem. 1991, 266, 16842-16846. [CrossRef]

66. Macpherson, J.A.; Theisen, A.; Masino, L.; Fets, L.; Driscoll, P.C.; Encheva, V.; Snijders, A.P.; Martin, S.R.; Kleinjung, J.; Barran, P.E.; et al. Functional cross-talk between allosteric effects of activating and inhibiting ligands underlies PKM2 regulation. Elife 2019, 8, e45068. [CrossRef] [PubMed] 
67. Peeters, K.; Van Leemputte, F.; Fischer, B.; Bonini, B.M.; Quezada, H.; Tsytlonok, M.; Haesen, D.; Vanthienen, W.; Bernardes, N.; Gonzalez-Blas, C.B.; et al. Fructose-1,6-bisphosphate couples glycolytic flux to activation of Ras. Nat. Commun. 2017, 8, 922. [CrossRef] [PubMed]

68. Das, J.; Ho, M.; Zikherman, J.; Govern, C.; Yang, M.; Weiss, A.; Chakraborty, A.K.; Roose, J.P. Digital Signaling and Hysteresis Characterize Ras Activation in Lymphoid Cells. Cell 2009, 136, 337-351. [CrossRef] [PubMed]

69. Gupta, S.; Ramjaun, A.R.; Haiko, P.; Wang, Y.; Warne, P.H.; Nicke, B.; Nye, E.; Stamp, G.; Alitalo, K.; Downward, J. Binding of Ras to Phosphoinositide 3-Kinase p110 $\alpha$ Is Required for Ras- Driven Tumorigenesis in Mice. Cell 2007, 129, 957-968. [CrossRef]

70. Lim, S.-O.; Li, C.-W.; Xia, W.; Lee, H.-H.; Chang, S.-S.; Shen, J.; Hsu, J.L.; Raftery, D.; Djukovic, D.; Gu, H.; et al. EGFR Signaling Enhances Aerobic Glycolysis in Triple-Negative Breast Cancer Cells to Promote Tumor Growth and Immune Escape. Cancer Res. 2016, 76, 1284-1296. [CrossRef]

71. Minchenko, O.; Opentanova, I.; Caro, J. Hypoxic regulation of the 6-phosphofructo-2-kinase/fructose-2,6-bisphosphatase gene family (PFKFB-1-4) expression in vivo. FEBS Lett. 2003, 554, 264-270. [CrossRef]

72. Wang, Z.; Dong, C. Gluconeogenesis in Cancer: Function and Regulation of PEPCK, FBPase, and G6Pase. Trends Cancer 2019, 5 , 30-45. [CrossRef]

73. Chae, Y.C.; Vaira, V.; Caino, M.C.; Tang, H.-Y.Y.; Seo, J.H.; Kossenkov, A.V.; Ottobrini, L.; Martelli, C.; Lucignani, G.; Bertolini, I.; et al. Mitochondrial Akt Regulation of Hypoxic Tumor Reprogramming. Cancer Cell 2016, 30, 257-272. [CrossRef]

74. Courtnay, R.; Ngo, D.C.; Malik, N.; Ververis, K.; Tortorella, S.M.; Karagiannis, T.C. Cancer metabolism and the Warburg effect: The role of HIF-1 and PI3K. Mol. Biol. Rep. 2015, 42, 841-851. [CrossRef] [PubMed]

75. Wang, T.-A.; Zhang, X.-D.; Guo, X.-Y.; Xian, S.-L.; Lu, Y.-F. 3-Bromopyruvate and sodium citrate target glycolysis, suppress survivin, and induce mitochondrial-mediated apoptosis in gastric cancer cells and inhibit gastric orthotopic transplantation tumor growth. Oncol. Rep. 2016, 35, 1287-1296. [CrossRef]

76. Guo, X.; Zhang, X.; Wang, T.; Xian, S.; Lu, Y. 3-Bromopyruvate and sodium citrate induce apoptosis in human gastric cancer cell line MGC-803 by inhibiting glycolysis and promoting mitochondria-regulated apoptosis pathway. Biochem. Biophys. Res. Commun. 2016, 475, 37-43. [CrossRef]

77. Ren, J.-G.; Seth, P.; Ye, H.; Guo, K.; Hanai, J.; Husain, Z.; Sukhatme, V.P. Citrate Suppresses Tumor Growth in Multiple Models through Inhibition of Glycolysis, the Tricarboxylic Acid Cycle and the IGF-1R Pathway. Sci. Rep. 2017, 7, 4537. [CrossRef] [PubMed]

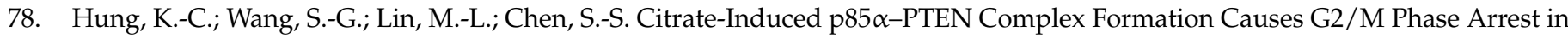
Human Pharyngeal Squamous Carcinoma Cell Lines. Int. J. Mol. Sci. 2019, 20, 2105. [CrossRef] [PubMed]

79. Li, Z.; Levine, K.M.; Bahreini, A.; Wang, P.; Chu, D.; Park, B.H.; Oesterreich, S.; Lee, A.V. Upregulation of IRS1 Enhances IGF1 Response in Y537S and D538G ESR1 Mutant Breast Cancer Cells. Endocrinology 2018, 159, 285-296. [CrossRef]

80. Icard, P.; Wu, Z.; Fournel, L.; Coquerel, A.; Lincet, H.; Alifano, M. ATP citrate lyase: A central metabolic enzyme in cancer. Cancer Lett. 2020, 471, 125-134. [CrossRef] [PubMed]

81. Icard, P.; Lincet, H. Corrigendum to "The reduced concentration of citrate in cancer cells: An indicator of cancer aggressiveness and a possible therapeutic target". Drug Resist. Update 2017, 30, 63. [CrossRef]

82. Berwick, D.C.; Hers, I.; Heesom, K.J.; Moule, S.K.; Tavareá, J.M. The Identification of ATP-citrate Lyase as a Protein Kinase B (Akt) Substrate in Primary Adipocytes. J. Biol. Chem. 2002, 277, 33895-33900. [CrossRef]

83. Bauer, D.E.; Hatzivassiliou, G.; Zhao, F.; Andreadis, C.; Thompson, C.B. ATP citrate lyase is an important component of cell growth and transformation. Oncogene 2005, 24, 6314-6322. [CrossRef]

84. Potapova, I.A.; El-Maghrabi, M.R.; Doronin, S.V.; Benjamin, W.B. Phosphorylation of Recombinant Human ATP:Citrate Lyase by cAMP-Dependent Protein Kinase Abolishes Homotropic Allosteric Regulation of the Enzyme by Citrate and Increases the Enzyme Activity. Allosteric Activation of ATP:Citrate Lyase by Phosphorylated Sug. Biochemistry 2000, 39, 1169-1179. [CrossRef]

85. Zhao, J.; Zhang, X.; Gao, T.; Wang, S.; Hou, Y.; Yuan, P.; Yang, Y.; Yang, T.; Xing, J.; Li, J.; et al. SIK2 enhances synthesis of fatty acid and cholesterol in ovarian cancer cells and tumor growth through PI3K/Akt signaling pathway. Cell Death Dis. 2020, 11, 25. [CrossRef]

86. Lee, J.V.; Carrer, A.; Shah, S.; Snyder, N.W.; Wei, S.; Venneti, S.; Worth, A.J.; Yuan, Z.F.; Lim, H.W.; Liu, S.; et al. Akt-dependent metabolic reprogramming regulates tumor cell Histone acetylation. Cell Metab. 2014, 20, 306-319. [CrossRef] [PubMed]

87. Hanai, J.I.; Doro, N.; Sasaki, A.T.; Kobayashi, S.; Cantley, L.C.; Seth, P.; Sukhatme, V.P. Inhibition of lung cancer growth: ATP citrate lyase knockdown and statin treatment leads to dual blockade of mitogen-activated protein Kinase (MAPK) and Phosphatidylinositol-3-kinase (PI3K)/AKT pathways. J. Cell. Physiol. 2012, 227, 1709-1720. [CrossRef]

88. Hanai, J.; Doro, N.; Seth, P.; Sukhatme, V.P. ATP citrate lyase knockdown impacts cancer stem cells in vitro. Cell Death Dis. 2013, 4, e696. [CrossRef]

89. Han, Q.; Chen, C.-A.; Yang, W.; Liang, D.; Lv, H.-W.; Lv, G.-S.; Zong, Q.-N.; Wang, H.-Y. ATP-citrate lyase regulates stemness and metastasis in hepatocellular carcinoma via the Wnt/ $\beta$-catenin signaling pathway. Hepatobiliary Pancreat. Dis. Int. 2020, in press. [CrossRef]

90. Lecarpentier, Y.; Schussler, O.; Hébert, J.-L.; Vallée, A. Multiple Targets of the Canonical WNT/ $\beta$-Catenin Signaling in Cancers. Front. Oncol. 2019, 9, 1248. [CrossRef] 
91. Lee, S.; Choi, E.J.; Cho, E.J.; Lee, Y.B.; Lee, J.-H.; Yu, S.J.; Yoon, J.-H.; Kim, Y.J. Inhibition of PI3K/Akt signaling suppresses epithelial-to-mesenchymal transition in hepatocellular carcinoma through the Snail/GSK-3/beta-catenin pathway. Clin. Mol. Hepatol. 2020, 26, 529-539. [CrossRef] [PubMed]

92. Singh, A.; Settleman, J. EMT, cancer stem cells and drug resistance: An emerging axis of evil in the war on cancer. Oncogene 2010, 29, 4741-4751. [CrossRef] [PubMed]

93. Lincet, H.; Icard, P. How do glycolytic enzymes favour cancer cell proliferation by nonmetabolic functions? Oncogene 2015, 34, 3751-3759. [CrossRef]

94. Jacquin, M.A.; Chiche, J.; Zunino, B.; Bénéteau, M.; Meynet, O.; Pradelli, L.A.; Marchetti, S.; Cornille, A.; Carles, M.; Ricci, J.-E. GAPDH binds to active Akt, leading to Bcl-xL increase and escape from caspase-independent cell death. Cell Death Differ. 2013, 20, 1043-1054. [CrossRef]

95. Carujo, S.; Estanyol, J.M.; Ejarque, A.; Agell, N.; Bachs, O.; Pujol, M.J. Glyceraldehyde 3-phosphate dehydrogenase is a SETbinding protein and regulates cyclin B-cdk1 activity. Oncogene 2006, 25, 4033-4042. [CrossRef]

96. Rodrigues, L.M.; Uribe-Lewis, S.; Madhu, B.; Honess, D.J.; Stubbs, M.; Griffiths, J.R. The action of $\beta$-hydroxybutyrate on the growth, metabolism and global histone $\mathrm{H} 3$ acetylation of spontaneous mouse mammary tumours: Evidence of a $\beta$ hydroxybutyrate paradox. Cancer Metab. 2017, 5, 4. [CrossRef]

97. Nieman, K.M.; Kenny, H.A.; Penicka, C.V.; Ladanyi, A.; Buell-Gutbrod, R.; Zillhardt, M.R.; Romero, I.L.; Carey, M.S.; Mills, G.B.; Hotamisligil, G.S.; et al. Adipocytes promote ovarian cancer metastasis and provide energy for rapid tumor growth. Nat. Med. 2011, 17, 1498-1503. [CrossRef]

98. Visweswaran, M.; Arfuso, F.; Warrier, S.; Dharmarajan, A. Aberrant lipid metabolism as an emerging therapeutic strategy to target cancer stem cells. Stem Cells 2020, 38, 6-14. [CrossRef]

99. Camarda, R.; Zhou, A.Y.; Kohnz, R.A.; Balakrishnan, S.; Mahieu, C.; Anderton, B.; Eyob, H.; Kajimura, S.; Tward, A.; Krings, G.; et al. Inhibition of fatty acid oxidation as a therapy for MYC-overexpressing triple-negative breast cancer. Nat. Med. 2016, 22, 427-432. [CrossRef]

100. Ito, K.; Carracedo, A.; Weiss, D.; Arai, F.; Ala, U.; Avigan, D.E.; Schafer, Z.T.; Evans, R.M.; Suda, T.; Lee, C.-H.; et al. A PML-PPAR$\delta$ pathway for fatty acid oxidation regulates hematopoietic stem cell maintenance. Nat. Med. 2012, 18, 1350-1358. [CrossRef] [PubMed]

101. Carracedo, A.; Weiss, D.; Leliaert, A.K.; Bhasin, M.; de Boer, V.C.J.; Laurent, G.; Adams, A.C.; Sundvall, M.; Song, S.J.; Ito, K.; et al. A metabolic prosurvival role for PML in breast cancer. J. Clin. Investig. 2012, 122, 3088-3100. [CrossRef] [PubMed]

102. Mihaylova, M.M.; Shaw, R.J. The AMPK signalling pathway coordinates cell growth, autophagy and metabolism. Nat. Cell Biol. 2011, 13, 1016-1023. [CrossRef] [PubMed]

103. Chen, L.; Liu, T.; Zhou, J.; Wang, Y.; Wang, X.; Di, W.; Zhang, S. Citrate synthase expression affects tumor phenotype and drug resistance in human ovarian carcinoma. PLoS ONE 2014, 9, e115708. [CrossRef] [PubMed]

104. Schlichtholz, B.; Turyn, J.; Goyke, E.; Biernacki, M.; Jaskiewicz, K.; Sledzinski, Z.; Swierczynski, J. Enhanced citrate synthase activity in human pancreatic cancer. Pancreas 2005, 30, 99-104. [CrossRef]

105. Aleskandarany, M.A.; Negm, O.H.N.; Rakha, E.A.; Ahmed, M.A.H.; Nolan, C.C.; Ball, G.R.; Caldas, C.; Green, A.R.; Tighe, P.J.; Ellis, I.O. TOMM34 expression in early invasive breast cancer: A biomarker associated with poor outcome. Breast Cancer Res. Treat. 2012, 136, 419-427. [CrossRef]

106. Icard, P.; Kafara, P.; Steyaert, J.-M.; Schwartz, L.; Lincet, H. The metabolic cooperation between cells in solid cancer tumors. Biochim. Biophys. Acta Rev. Cancer 2014, 1846, 216-225. [CrossRef] [PubMed]

107. Curry, J.M.; Tuluc, M.; Whitaker-Menezes, D.; Ames, J.A.; Anantharaman, A.; Butera, A.; Leiby, B.; Cognetti, D.; Sotgia, F.; Lisanti, M.P.; et al. Cancer metabolism, stemness and tumor recurrence. Cell Cycle 2013, 12, 1371-1384. [CrossRef] [PubMed]

108. Bonuccelli, G.; Tsirigos, A.; Whitaker-Menezes, D.; Pavlides, S.; Pestell, R.G.; Chiavarina, B.; Frank, P.G.; Flomenberg, N.; Howell, A.; Martinez-Outschoorn, U.E.; et al. Ketones and lactate "fuel" tumor growth and metastasis. Cell Cycle 2010, 9, 3506-3514. [CrossRef]

109. Corbet, C.; Pinto, A.; Martherus, R.; Santiago de Jesus, J.P.; Polet, F.; Feron, O. Acidosis Drives the Reprogramming of Fatty Acid Metabolism in Cancer Cells through Changes in Mitochondrial and Histone Acetylation. Cell Metab. 2016, 24, 311-323. [CrossRef] [PubMed]

110. Hillar, M.; Lott, V.; Lennox, B. Correlation of the effects of citric acid cycle metabolites on succinate oxidation by rat liver mitochondria and submitochondrial particles. J. Bioenerg. 1975, 7, 1-15. [CrossRef]

111. Fink, B.D.; Bai, F.; Yu, L.; Sheldon, R.D.; Sharma, A.; Taylor, E.B.; Sivitz, W.I. Oxaloacetic acid mediates ADP-dependent inhibition of mitochondrial complex II-driven respiration. J. Biol. Chem. 2018, 293, 19932-19941. [CrossRef] [PubMed]

112. Bae, J.; Salamon, R.J.; Brandt, E.B.; Paltzer, W.G.; Zhang, Z.; Britt, E.C.; Hacker, T.A.; Fan, J.; Mahmoud, A.I. Malonate Promotes Adult Cardiomyocyte Proliferation and Heart Regeneration. Circulation 2021, 143, 1973-1986. [CrossRef]

113. Eidelman, E.; Twum-Ampofo, J.; Ansari, J.; Siddiqui, M.M. The Metabolic Phenotype of Prostate Cancer. Front. Oncol. 2017, 7, 131. [CrossRef]

114. Liu, Y. Fatty acid oxidation is a dominant bioenergetic pathway in prostate cancer. Prostate Cancer Prostatic Dis. 2006, 9, 230-234. [CrossRef] [PubMed]

115. Costello, L.C.; Franklin, R.B. A comprehensive review of the role of zinc in normal prostate function and metabolism; and its implications in prostate cancer. Arch. Biochem. Biophys. 2016, 611, 100-112. [CrossRef] 
116. Andersen, M.K.; Høiem, T.S.; Claes, B.S.R.; Balluff, B.; Martin-Lorenzo, M.; Richardsen, E.; Krossa, S.; Bertilsson, H.; Heeren, R.M.A.; Rye, M.B.; et al. Spatial differentiation of metabolism in prostate cancer tissue by MALDI-TOF MSI. Cancer Metab. 2021, 9, 9. [CrossRef] [PubMed]

117. Giskeødegård, G.F.; Bertilsson, H.; Selnæs, K.M.; Wright, A.J.; Bathen, T.F.; Viset, T.; Halgunset, J.; Angelsen, A.; Gribbestad, I.S.; Tessem, M.-B. Spermine and Citrate as Metabolic Biomarkers for Assessing Prostate Cancer Aggressiveness. PLoS ONE 2013, 8, e62375. [CrossRef]

118. Campbell, P.N.; Smith, A.D.; Peters, T.J. Biochemistry Illustrated; Churchill Livingstone: London, UK, 2005; ISBN 978-0443100345.

119. Caruana, I.; Simula, L.; Locatelli, F.; Campello, S. T lymphocytes against solid malignancies: Winning ways to defeat tumours. Cell Stress 2018, 2, 200-212. [CrossRef]

120. Ho, P.-C.; Liu, P.-S. Metabolic communication in tumors: A new layer of immunoregulation for immune evasion. J. Immunother. Cancer 2016, 4, 4. [CrossRef]

121. Chang, C.H.; Qiu, J.; O’Sullivan, D.; Buck, M.D.; Noguchi, T.; Curtis, J.D.; Chen, Q.; Gindin, M.; Gubin, M.M.; van der Windt, G.J.W.; et al. Metabolic Competition in the Tumor Microenvironment Is a Driver of Cancer Progression. Cell 2015, 162, 1229-1241. [CrossRef] [PubMed]

122. Sukumar, M.; Roychoudhuri, R.; Restifo, N.P. Nutrient Competition: A New Axis of Tumor Immunosuppression. Cell 2015, 162, 1206-1208. [CrossRef]

123. Michalek, R.D.; Gerriets, V.A.; Jacobs, S.R.; Macintyre, A.N.; MacIver, N.J.; Mason, E.F.; Sullivan, S.A.; Nichols, A.G.; Rathmell, J.C. Cutting edge: Distinct glycolytic and lipid oxidative metabolic programs are essential for effector and regulatory CD4+ T cell subsets. J. Immunol. 2011, 186, 3299-3303. [CrossRef]

124. Rueda, C.M.; Rodríguez-Perea, A.L.; Moreno-Fernandez, M.; Jackson, C.M.; Melchior, J.T.; Davidson, W.S.; Chougnet, C.A. High density lipoproteins selectively promote the survival of human regulatory T cells. J. Lipid Res. 2017, 58, 1514-1523. [CrossRef]

125. Cho, Y.; Cho, E.J.; Lee, J.-H.; Yu, S.J.; Kim, Y.J.; Kim, C.Y.; Yoon, J.-H. Hypoxia Enhances Tumor-Stroma Crosstalk that Drives the Progression of Hepatocellular Carcinoma. Dig. Dis. Sci. 2016, 61, 2568-2577. [CrossRef]

126. Pavlides, S.; Whitaker-Menezes, D.; Castello-Cros, R.; Flomenberg, N.; Witkiewicz, A.K.; Frank, P.G.; Casimiro, M.C.; Wang, C.; Fortina, P.; Addya, S.; et al. The reverse Warburg effect: Aerobic glycolysis in cancer associated fibroblasts and the tumor stroma. Cell Cycle 2009, 8, 3984-4001. [CrossRef]

127. Icard, P.; Loi, M.; Wu, Z.; Ginguay, A.; Lincet, H.; Robin, E.; Coquerel, A.; Berzan, D.; Fournel, L.; Alifano, M. Metabolic Strategies for Inhibiting Cancer Development. Adv. Nutr. 2021, nmaa174. [CrossRef] [PubMed]

128. Weiss, J.M.; Davies, L.C.; Karwan, M.; Ileva, L.; Ozaki, M.K.; Cheng, R.Y.S.; Ridnour, L.A.; Annunziata, C.M.; Wink, D.A.; McVicar, D.W. Itaconic acid mediates crosstalk between macrophage metabolism and peritoneal tumors. J. Clin. Investig. 2018, 128, 3794-3805. [CrossRef]

129. O'Neill, L.A.J.; Artyomov, M.N. Itaconate: The poster child of metabolic reprogramming in macrophage function. Nat. Rev. Immunol. 2019, 19, 273-281. [CrossRef] [PubMed]

130. Mycielska, M.E.; Dettmer, K.; Rümmele, P.; Schmidt, K.; Prehn, C.; Milenkovic, V.M.; Jagla, W.; Madej, G.M.; Lantow, M.; Schladt, M.; et al. Extracellular Citrate Affects Critical Elements of Cancer Cell Metabolism and Supports Cancer Development In Vivo. Cancer Res. 2018, 78, 2513-2523. [CrossRef]

131. Haferkamp, S.; Drexler, K.; Federlin, M.; Schlitt, H.J.; Berneburg, M.; Adamski, J.; Gaumann, A.; Geissler, E.K.; Ganapathy, V.; Parkinson, E.K.; et al. Extracellular Citrate Fuels Cancer Cell Metabolism and Growth. Front. Cell Dev. Biol. 2020, 8, 1518. [CrossRef]

132. Petillo, A.; Abruzzese, V.; Koshal, P.; Ostuni, A.; Bisaccia, F. Extracellular Citrate Is a Trojan Horse for Cancer Cells. Front. Mol. Biosci. 2020, 7, 593866. [CrossRef] [PubMed]

133. Costello, L.C.; Franklin, R.B. The implications of the hypocitricemic response to surgery and the role of liver function and hepatocyte metabolism: An important, but neglected, clinical relationship. Liver Res. Disord. Ther. 2018, 4, 114-119. [CrossRef] [PubMed]

134. Granchi, D.; Baldini, N.; Ulivieri, F.M.; Caudarella, R. Role of Citrate in Pathophysiology and Medical Management of Bone Diseases. Nutrients 2019, 11, 2576. [CrossRef]

135. Yi, C.H.; Pan, H.; Seebacher, J.; Jang, I.-H.; Hyberts, S.G.; Heffron, G.J.; Vander Heiden, M.G.; Yang, R.; Li, F.; Locasale, J.W.; et al. Metabolic Regulation of Protein N-Alpha-Acetylation by Bcl-xL Promotes Cell Survival. Cell 2011, 146, 607-620. [CrossRef]

136. Jeong, Y.-M.M.; Lee, J.E.; Kim, S.Y.; Yun, H.-Y.Y.; Baek, K.J.; Kwon, N.S.; Kim, D.-S.S. Enhanced effects of citrate on UVB-induced apoptosis of B16 melanoma cells. Pharmazie 2009, 64, 829-833. [CrossRef]

137. Kruspig, B.; Nilchian, A.; Orrenius, S.; Zhivotovsky, B.; Gogvadze, V. Citrate kills tumor cells through activation of apical caspases. Cell. Mol. Life Sci. 2012, 69, 4229-4237. [CrossRef]

138. El Sayed, S.M.; El-Magd, R.M.A.; Shishido, Y.; Yorita, K.; Chung, S.P.; Tran, D.H.; Sakai, T.; Watanabe, H.; Kagami, S.; Fukui, K. D-Amino acid oxidase-induced oxidative stress, 3-bromopyruvate and citrate inhibit angiogenesis, exhibiting potent anticancer effects. J. Bioenerg. Biomembr. 2012, 44, 513-523. [CrossRef] [PubMed]

139. Xu, X.; LI, B.; Huang, P.; Wan, X.; Qin, Y.; Zhou, L.; Liu, H.; Bai, H.; Gao, Y.; Wang, C.; et al. Citrate induces apoptosis of the acute monocytic leukemia U937 cell line through regulation of HIF-1 $\alpha$ signaling. Mol. Med. Rep. 2013, 8, 1379-1384. [CrossRef]

140. Chen, X.; Lv, Q.; Liu, Y.; Deng, W. Effect of food additive citric acid on the growth of human esophageal carcinoma cell line EC109. Cell J. 2016, 18, 493-502. [CrossRef] [PubMed] 
141. Xia, Y.; Zhang, X.; Bo, A.; Sun, J.; Li, M. Sodium citrate inhibits the proliferation of human gastric adenocarcinoma epithelia cells. Oncol. Lett. 2018, 15, 6622-6628. [CrossRef] [PubMed]

142. Abe, K.; Yamamoto, N.; Hayashi, K.; Takeuchi, A.; Tsuchiya, H. Caffeine citrate enhanced cisplatin antitumor effects in osteosarcoma and fibrosarcoma in vitro and in vivo. BMC Cancer 2019, 19, 689. [CrossRef]

143. Fagundes, D.A.; Leonel, L.V.; Fernandez-Outon, L.E.; Ardisson, J.D.; dos Santos, R.G. Radiosensitizing effects of citrate-coated cobalt and nickel ferrite nanoparticles on breast cancer cells. Nanomedicine 2020, 15, 2823-2836. [CrossRef] [PubMed]

144. Zhou, S.; Sakamoto, K. Citric acid promoted melanin synthesis in B16F10 mouse melanoma cells, but inhibited it in human epidermal melanocytes and HMVII melanoma cells via the GSK3 $\beta$ / $\beta$-catenin signaling pathway. PLoS ONE 2020, 15, e0243565. [CrossRef]

145. Fan, X.; Zhou, J.; Yan, X.; Bi, X.; Liang, J.; Lu, S.; Luo, L.; Zhou, D.; Yin, Z. Citrate activates autophagic death of prostate cancer cells via downregulation CaMKII/AKT/mTOR pathway. Life Sci. 2021, 275, 119355. [CrossRef] [PubMed]

146. Ando, H.; Eshima, K.; Ishida, T. Neutralization of Acidic Tumor Microenvironment (TME) with Daily Oral Dosing of Sodium Potassium Citrate (K/Na Citrate) Increases Therapeutic Effect of Anti-cancer Agent in Pancreatic Cancer Xenograft Mice Model. Biol. Pharm. Bull. 2021, 44, 266-270. [CrossRef]

147. Iacobazzi, V.; Infantino, V. Citrate-new functions for an old metabolite. Biol. Chem. 2014, 395, 387-399. [CrossRef]

148. Huang, L.; Wang, C.; Xu, H.; Peng, G. Targeting citrate as a novel therapeutic strategy in cancer treatment. Biochim. Biophys. Acta Rev. Cancer 2020, 1873, 188332. [CrossRef] [PubMed]

149. Philippe, I.; Lincet, $\mathrm{H}$. The reduced concentration of citrate in cancer cells: An indicator of cancer aggressiveness and a possible therapeutic target. Drug Resist. Update 2016, 29, 47-53. [CrossRef]

150. Simon-Molas, H.; Arnedo-Pac, C.; Fontova, P.; Vidal-Alabró, A.; Castaño, E.; Rodríguez-García, A.; Navarro-Sabaté, À.; Lloberas, N.; Manzano, A.; Bartrons, R. PI3K-Akt signaling controls PFKFB3 expression during human T-lymphocyte activation. Mol. Cell. Biochem. 2018, 448, 187-197. [CrossRef]

151. Mottet, D.; Dumont, V.; Deccache, Y.; Demazy, C.; Ninane, N.; Raes, M.; Michiels, C. Regulation of hypoxia-inducible factor-1 $\alpha$ protein level during hypoxic conditions by the phosphatidylinositol 3-kinase/Akt/glycogen synthase kinase $3 \beta$ pathway in HepG2 cells. J. Biol. Chem. 2003, 278, 31277-31285. [CrossRef]

152. Raghunand, N.; He, X.; van Sluis, R.; Mahoney, B.; Baggett, B.; Taylor, C.W.; Paine-Murrieta, G.; Roe, D.; Bhujwalla, Z.M.; Gillies, R.J.; et al. Enhancement of chemotherapy by manipulation of tumour pH. Br. J. Cancer 1999, 80, 1005-1011. [CrossRef]

153. Faes, S.; Duval, A.P.; Planche, A.; Uldry, E.; Santoro, T.; Pythoud, C.; Stehle, J.-C.C.; Horlbeck, J.; Letovanec, I.; Riggi, N.; et al. Acidic tumor microenvironment abrogates the efficacy of mTORC1 inhibitors. Mol. Cancer 2016, 15, 78. [CrossRef] [PubMed]

154. Pilon-Thomas, S.; Kodumudi, K.N.; El-Kenawi, A.E.; Russell, S.; Weber, A.M.; Luddy, K.; Damaghi, M.; Wojtkowiak, J.W.; Mulé, J.J.; Ibrahim-Hashim, A.; et al. Neutralization of Tumor Acidity Improves Antitumor Responses to Immunotherapy. Cancer Res. 2016, 76, 1381-1390. [CrossRef] [PubMed]

155. Mycielska, M.E.; Geissler, E.K. Extracellular Citrate and Cancer Metabolism-Response. Cancer Res. 2018, 78, 5177. [CrossRef]

156. Caiazza, C.; D’Agostino, M.; Passaro, F.; Faicchia, D.; Mallardo, M.; Paladino, S.; Pierantoni, G.M.; Tramontano, D. Effects of Long-Term Citrate Treatment in the PC3 Prostate Cancer Cell Line. Int. J. Mol. Sci. 2019, 20, 2613. [CrossRef]

157. Guo, J.Y.; White, E. Autophagy is required for mitochondrial function, lipid metabolism, growth, and fate of KRAS G12D -driven lung tumors. Autophagy 2013, 9, 1636-1638. [CrossRef]

158. Schug, Z.T.; Vande Voorde, J.; Gottlieb, E. The metabolic fate of acetate in cancer. Nat. Rev. Cancer 2016, 16, 708-717. [CrossRef] [PubMed]

159. Diaz-Moralli, S.; Aguilar, E.; Marin, S.; Coy, J.F.; Dewerchin, M.; Antoniewicz, M.R.; Meca-Cortés, O.; Notebaert, L.; Ghesquière, B.; Eelen, G.; et al. A key role for transketolase-like 1 in tumor metabolic reprogramming. Oncotarget 2016, 7, 51875-51897. [CrossRef] [PubMed]

160. Singh, S. Preclinical Pharmacokinetics: An Approach Towards Safer and Efficacious Drugs. Curr. Drug Metab. 2006, 7, 165-182. [CrossRef] [PubMed]

161. D’Angelo, A.; Sobhani, N.; Chapman, R.; Bagby, S.; Bortoletti, C.; Traversini, M.; Ferrari, K.; Voltolini, L.; Darlow, J.; Roviello, G. Focus on ROS1-Positive Non-Small Cell Lung Cancer (NSCLC): Crizotinib, Resistance Mechanisms and the Newer Generation of Targeted Therapies. Cancers 2020, 12, 3293. [CrossRef] [PubMed]

162. Romaniello, D.; Marrocco, I.; Belugali Nataraj, N.; Ferrer, I.; Drago-Garcia, D.; Vaknin, I.; Oren, R.; Lindzen, M.; Ghosh, S.; Kreitman, M.; et al. Targeting HER3, a Catalytically Defective Receptor Tyrosine Kinase, Prevents Resistance of Lung Cancer to a Third-Generation EGFR Kinase Inhibitor. Cancers 2020, 12, 2394. [CrossRef] 